\title{
Księgi korporacji rzemieślniczych Proszowic z XV wieku Przyczynek do badań nad piśmiennictwem miejskim w średniowieczu
}

\section{Wstęp}

Wśród zabytków średniowiecznego piśmiennictwa mieszczańskiego w Polsce zachowało się niewiele ksiąg wpisów prowadzonych przez korporacje rzemieślnicze - cechy i bractwa cechowe. W dodatku wiedza o wytworach kancelarii rzemieślniczych jest nikła. W literaturze naukowej wzmiankowanych jest zaledwie kilka ksiąg cechowych i brackich z XIV oraz XV wieku i to głównie dotyczących miast większych (Kraków, Poznań, Toruń). Przy tym najczęściej wykorzystywano je jedynie jako źródła w opracowaniach o szerszej problematyce ${ }^{1}$ Zasadniczo brakuje odrębnych studiów źródłoznawczych

1 A. Bartoszewicz: Piśmienność mieszczańska w średniowiecznej Polsce. Warszawa 2012, s. 118 -122; J. Tandecki: Dokumenty i kancelarie miejskie. W: Dyplomatyka staropolska. Red. T. Jurek. Warszawa 2015, s. 435-442; H. Zaremska: Bractwa w średniowiecznym Krakowie. Studium form społecznego życia religijnego. Wrocław-Warszawa-Kraków_Gdańsk 1977, s. 9-11, 186-190 (omówienie podstawy źródłowej pracy i wykaz źródeł). Nawet w pracy J. Tandeckiego poświęconej kancelarii korporacji rzemieślniczych z Torunia brak inwentarza zachowanych ksiąg oraz ich opisu. Wzmianki o zachowanych księgach korporacyjnych pojawiają się w treści opracowania. Autor sporządził Wykaz zespołów toruńskich cechów, korporacji religijnych $i$ bractw czeladniczych posiadajacych akta z okresu staropolskiego, ale archiwalia zostały w nim potraktowane łącznie — brak rozróżnienia na dokumenty i księgi wpisów. 
poświęconych rękopisom oraz opracowań analitycznych dotyczących kancelarii korporacyjnych. Tylko niektóre z wytworów aktowych, jak księgi cechu złotników krakowskich, zostały wydane oraz szczegółowo wykorzystane w opracowaniach monograficznych ${ }^{2}$. Wyjątkiem są też szczegółowe studia nad kancelariami korporacji rzemieślniczych Torunia autorstwa Janusza Tandeckiego ${ }^{3}$. Umykają za to badaczom piśmiennictwa mieszczańskiego średniowieczne akta korporacyjne miast średnich i mniejszych, choć niektóre były już wykorzystywane w opracowaniach naukowych — jak księga cechu sukienników Kleparza (z wpisami od 1423 roku) ${ }^{4}$ czy księga bractwa cechowego kowali z Bochni (z wpisami od 1462 roku) $)^{5}$. Wydaje się więc, że ubóstwo wiedzy o księgach korporacyjnych jest w głównej mierze efektem braku kompleksowych badań nad tą problematyką oraz słabego rozpoznania źródeł miejskich w ogóle. Z dużym prawdopodobieństwem można też założyć, że istnieją jeszcze inne zabytki miejskiego piśmiennictwa korporacyjnego — nieodkryte lub niezidentyfikowane.

Przykładem na poparcie tej tezy jest dokumentacja korporacyjna z małopolskiego miasta Proszowice. Choć w Bibliotece Jagiellońskiej w Krakowie zachował się rękopis księgi prowadzonej przez cech kowali, to w opracowa-

Por. J. Tandecki: Kancelarie toruńskich korporacji rzemieślniczych $w$ okresie staropolskim. Warszawa-Poznań-Toruń 1987 (Roczniki Towarzystwa Naukowego w Toruniu, 82, z. 3), s. 42-65, tabela 2; Tenże: Średniowieczne i nowożytne źródta do dziejów rzemiost skórniczych. W: Tenże: Szkice z dziejów Torunia i Prus w średniowieczu i na progu czasów nowożytnych. Toruń 2008, s. 163-166.

2 J. Pietrusiński: Złotnicy krakowscy XIV-XVI wieku i ich cech. Warszawa 2000 (Złotnicy krakowscy XIV-XVI wieku i ich księga cechowa, T. 1); Księga cechowa złotników krakowskich 1462-1566. Tekst oprac. B. Dybaś, J. Tandecki. Warszawa 2000 (Złotnicy krakowscy XIV-XVI wieku i ich księga cechowa, T. 2).

3 J. Tandecki: Kancelarie toruńskich korporacji rzemieślniczych...; Tenże: Struktury administracyjne $i$ społeczne oraz formy życia $w$ wielkich miastach Prus Krzyżackich i Królewskich w średniowieczu i na progu czasów nowożytnych. Toruń 2001, s. 75-82, 105-115. Korporacjom funkcjonującym w miastach państwa krzyżackiego poświęcone zostały odrębne monografie, ale ich autorzy nie zajęli się przy tym dokumentacją własną tych zrzeszeń. Por. I. Czarciński: Bractwa w wielkich miastach państwa krzyżackiego w średniowieczu. Toruń 1993; Z. Kropidłowski: Samopomoc w korporacjach rzemieślniczych Gdańska, Torunia i Elblaga (XIV-XVIII w.). Gdańsk 1997.

${ }^{4}$ Księga nie była znana A. Bartoszewicz (Piśmienność mieszczańska...), co zauważył w recenzji M. Starzyński (Rocz. Hist. 2012, T. 88, s. 318-319). Wcześniej cytował rękopis J. Wyrozumski: Tkactwo małopolskie w późnym średniowieczu. Warszawa-Kraków 1972, s. 14; Tenże: Związki czeladnicze w Polsce średniowiecznej. Prz. Hist. 1977, T. 68, s. 7. Ostatnio artykuł oparty m.in. na wspomnianym rękopisie napisał M. Schmidt, który też doprecyzował datę najstarszych wpisów - Tenże: Sąownictwo cechów krakowskich w średniowieczu w świetle ksiag cechowych. W: ZNUJ. Prace historyczne, nr 142, z. 1. Kraków 2015, s. $61-77$.

${ }^{5}$ F. Kiryk: Bractwo religijne kowali w Bochni w latach 1462-1559. W: ZNUJ. Prace historyczne, z. 56. Kraków 1977, s. 115-123. 
niach naukowych niemal on nie funkcjonuje. Oprócz opisów inwentarzowych i kodykologicznych ${ }^{6}$ wykorzystywali go w badaniach wyłącznie autorzy monografii Proszowic — Feliks Kiryk i Franciszek Leśniak ${ }^{7}$. Ale jednak i ci historycy nie dokonali gruntownej analizy ani charakterystyki tego zabytku piśmiennictwa ${ }^{8}$. Na początku XX wieku ks. Jan Wiśniewski odnalazł akta korporacji rzemieślniczej z Proszowic, rozpoczynające się wpisem datowanym na 1489 rok. Niestety poczynił o nich jedynie lakoniczną wzmiankę, określając je mianem „księgi cechowej szwieckiej”, i przytoczył początkowy nagłówkowy wpis (wraz z jego reprodukcją) $)^{9}$. Niestety losy tego rękopisu są dziś nieznane. Nie był za to dotąd wykorzystywany rękopis związany z działalnością innego

${ }^{6}$ W. Wisłocki: Katalog rękopisów Biblioteki Uniwersytetu Jagiellońskiego. Cz. 1. Kraków 1877, s. 286. Szczegółowy opis kodykologiczy sporządzili Maria Kowalczyk i Marian Zwiercan w: Catalogus codicum manuscriptorum medii aevi Latinorum qui in Bibliotheca Jagiellonica Cracoviae asservantur. Vol. 6. Composuerunt M. Kowalczyk, A. Kozłowska, M. Markowski, L. Nowak, A. Sobańska, R. Tatarzyński, S. Włodek, M. Zwiercan. Cracoviae 1996, s. 397399. Regest wpisu zawierającego statuty oraz podobizna odpisu tekstu ze s. $13-15$ rękopisu BJ 1111 — zob. Materiaty do Kodeksu dyplomatycznego Małopolski. T. 5: 1451-1506. Oprac. W. Bukowski, F. Sikora, J. Wroniszewski. Red. W. Bukowski, przy współpr. J. Szyszki. Kraków 2014, nr 1613 (P 34). Dostępne w Internecie: http://www.kodeks.pau.krakow.pl/dokumenty.html [data dostępu: 20.12.2020]. Podobizna całego rękopisu jest dostępna w wersji cyfrowej w Jagiellońskiej Bibliotece Cyfrowej: https://www.jbc.bj.uj.edu.pl/dlibra [data dostępu: 25.09.2020].

7 Jako pierwszy wykorzystał księgę w badaniach F. Kiryk, który jednak poświęcił jej tylko krótką wzmiankę, ograniczającą się głównie do podania daty jej założenia, według treści nagłówka, oraz wskazania zakresu chronologicznego wpisów. Por. Tenże: Dzieje Proszowic $w$ epoce piastowskiej $i$ jagiellońskiej. „Rocznik Naukowo-Dydaktyczny Wyższej Szkoły Pedagogicznej w Krakowie" 1967, z. 26, s. 37 (Prace Historyczne, z. 3); Tenże: Miasto średniowieczne. W: Proszowice. Zarys dziejów do 1939 roku. Red. F. Kiryk. Kraków 2000, s. 57-59. Zawartość wpisów z XV-XVIII w. wykorzystał F. Leśniak: W okresie Polski szlacheckiej. W: Proszowice. Zarys dziejów do 1939 roku. Red. F. Kiryk. Kraków 2000, s. 177-179, 187 i n. Ostatnio charakterystyka zawartości rękopisu: K. Nabiałek: Księgi miejskie Proszowic z XV-XVIII wieku. Studium kodykologiczne. „Archeion” 2019, T. 120, s. $316-317$.

${ }^{8}$ Brak podjęcia przez F. Kiryka pogłębionej analizy zawartości księgi kowali proszowickich dziwi, zważywszy, że historyk ten problematyce korporacji rzemieślniczych w miastach poświęcił odrębne studia: Tenże: Bractwo religijne kowali...; Tenże: Rzemiosła i organizacje rękodzielnicze w małopolskich miastach górniczych. „Teki Krakowskie” 1997, [T.] 5, s. $65-70$.

9 J. Wiśniewski: Dekanat miechowski. Radom 1917, s. 312-313. Autor podał, że jest to księga „Z XV-XVI wieku, podłużna po łacinie, gotyckimi literami pisana, złożona została przez piszącego w Arch. Kons. Kieleckiego". W Archiwum Diecezjalnym w Kielcach, w którym przechowywane są akta konsystorza kieleckiego, niestety nie udało się odnaleźć tego rękopisu. W monografii miasta zupełnie pominięto wzmiankę o księdze cechowej, a jedynie wykorzystano z zacytowanego przez ks. Wiśniewskiego nagłówka informację o ołtarzu św. Krzyża jako ołtarzu brackim szewców. Por. F. Kiryk: Miasto średniowieczne..., s. 57. 
proszowickiego zrzeszenia - bractwa i cechu krawców. Księga ta, a właściwie jej fragment w postaci składki, została zidentyfikowana ostatnio w Archiwum Diecezjalnym w Kielcach ${ }^{10}$.

Istnieją podstawy, by uznać, że oba rękopisy pochodzą z podobnego okresu. Kluczowe znaczenie ma tu identyfikacja papieru, na którym księgi spisano. W obu stwierdzono bowiem identyczny znak wodny (fot. 1). Przedstawia on zamkniętą koronę z krzyżem na podwójnym pręcie, o wymiarach $123 \times 47 \mathrm{~mm}$ oraz o rozstawie drutów $70 \mathrm{~mm}$. Porównanie jego kształtu i wymiarów z filigranami opublikowanymi w bazach pozwala uznać, że papier wykonano najpewniej w latach 80 . XV wieku. Identyczny znak datowany na 1488 rok pochodzi z Giebichenstein w Saksonii ${ }^{11}$, a podobne filigrany, również z terenu Niemiec, datowane są na lata 1489, 1490 i 1488 - 14912. Co więcej — ten sam filigran znajduje się także w księdze ławniczej Proszowic, na karcie a ściślej: na bifolium — z wpisami z 1489 i 1490 roku $^{13}$. Wydaje się więc uprawnione datowanie powstania obu rękopisów na lata 80. lub przełom lat 80. i 90. XV wieku, co postaram się w dalszej części uzasadnić dodatkowymi argumentami.

Niniejszy tekst poświęcony jest opisowi kodykologicznemu i charakterystyce zawartości obu rękopisów oraz próbie ustalenia, jaki był status tych korporacji w chwili założenia własnych ksiąg wpisów. Każdy z manuskryptów omówiony zostanie w oddzielnym punkcie.

${ }^{10}$ Archiwum Diecezjalne w Kielcach (dalej: ADK), Akta parafialne II, sygn. IIPP-XVI/1. Przypuszczam, że może to być fragment zaginionych akt, o których wzmiankował ks. J. Wiśniewski, co postaram się uzasadnić w dalszej części, tam też szerzej o odnalezionym rękopisie (zob. część niniejszego artykułu pt. Księga bractwa i cechu krawców).

${ }^{11} \mathrm{https}$ ://www.piccard-online.de/struktur.php?klassi=001\&anzeigeKlassi=001.006\&Id=10 1\&sprache $=\&$ weitere=struktur: nr 53215 [data dostępu: 22.01.2021].

${ }_{12}$ Z Giebichenstein dwa inne filigrany z 1489 r., z Rot, Kloster z 1489 r., z Wemding z 1490 r., z Miltenbergu z lat 1488-1491 (https://www.piccard-online.de/struktur.php?klass $\mathrm{i}=001$ \&anzeigeKlassi $=001.006 \& \mathrm{Id}=101 \&$ sprache $=$ \&weitere $=$ struktur: $\mathrm{nr} 53045,53218,53219$, 53220, 53436 [data dostępu: 22.01.2021]). Autorzy opisu kodykologicznego rękopisu uznali, że znak z papieru rkps 1111 jest identyczny z wymienionym wcześniej, datowanym na lata 1488-1491 (Catalogus..., s. 398).

13 ANKr, zespół nr 29/121/0: Variae civitates et villae, sygn. 29/121/0/-/167, s. 231-232 oraz nienumerowana karta przed s. 239. Wzmianka o tym znaku: K. Nabiałek: Ksieggi miejskie Proszowic..., s. 298. 


\section{Księga cechu kowali i innych rzemiosł}

Najstarszą zachowaną i zidentyfikowaną dokumentacją własną korporacji rzemieślniczej Proszowic jest księga cechu kowali, którą założono, jak zaznaczono we wpisie nagłówkowym, w ostatnim tygodniu 1483 roku. Chodzi tu o rękopis o sygnaturze 1111, przechowywany w Bibliotece Jagiellońskiej w Krakowie, w zbiorach której znalazł się prawdopodobnie z daru Józefa Kowalskiego $\mathrm{w} 1875 \mathrm{roku}^{14}$. Jest to kodeks papierowy o wymiarach kart $10,8 \times 32,1-32,8 \mathrm{~cm}$ (format dutki), umieszczonych $\mathrm{w}$ oprawie-obwolucie z miękkiej skóry, obecnie ściemniałej, do której od dołu przyszyte są składki. Rękopis posiada paginację ołówkową: s. 1—48, która odpowiada rzeczywistej liczbie kart (24).

Kodeks jest zbudowany z trzech składek - pierwsza: $3+3$ (s. 1-12), ze ściegiem $\mathrm{w}$ środku, za pomocą którego łączy się z oprawą; druga: $2+2$ (s. 13-20), ze śladami po szyciu w środku; trzecia: $7+7$ (s. $21-48$ ), ze ściegiem w środku. We wszystkich składkach występuje ten sam znak wodny (zamknięta korona z krzyżem na podwójnym pręcie), datowany na ok. 1488 rok (względnie lata 1488-1491), o czym już wspomniałem we wstępie. W składce pierwszej jest on na drugiej karcie (s. 3-4); w składce drugiej na pierwszej karcie (s. 13-14); w składce trzeciej na kartach: dziewiątej i częściowo szóstej (s. 37-38 i 31-32) oraz na trzynastej (s. 45-46). Występowanie tego samego filigranu na papierze wszystkich składek rękopisu pozwala stwierdzić, że księgę założono w tej postaci w XV wieku. Do rozstrzygnięcia pozostaje, czy powstała ona w 1483 roku (jak zapisano w nagłówku), czy też na przełomie lat 80. i 90. XV wieku (jak wynika z czasu powstania papieru). Jeżeli przyjąć czas powstania papieru na koniec lat 80 ., zgodnie $z$ datowaniem znaku wodnego, to można dopuścić możliwość, że wpisy sporządzono później, niż wskazują daty umieszczone w nagłówkach. Możliwe jednak, że papier był wyprodukowany kilka lat wcześniej niż wskazuje datacja filigranu. Może właśnie proszowicki rękopis poświadcza jego najstarsze użycie. Za tą drugą możliwością przemawia podanie 1483 roku w nagłówkach odrębnych wpisów w dwóch różnych składkach.

Obecny układ składek nie odpowiada wprawdzie kolejności chronologicznej wpisów (najstarsze są w składce drugiej - s. 13-15, oraz na początku składki trzeciej — s. 21), ale może mieć to związek bądź z niewłaściwym ich

${ }^{14}$ W. Wisłocki: Katalog rękopisów..., s. 286. M. Kowalczyk i M. Zwiercan zwracają uwagę, że o ile nota w rękopisie (BJ, rkps 1111, k. 1) oraz wpis w księdze akcesyjnej BJ informują, że rękopis podarował Józef Kowalski 30 kwietnia 1875 r. wraz z dwoma innymi rękopisami (o sygnaturach 1112 i 1113), o tyle w Liber benefactorum BJ zanotowano, że jest to dar Józefa Kownackiego ofiarowany razem z kodeksem o sygnaturze 1047 (Catalogus..., s. 398-399). 
wszyciem, bądź, co bardziej prawdopodobne, pierwsza składka celowo została wydzielona tematycznie i pozostawiona do późniejszego zapisania. Księga zawiera zasadniczo wpisy z XV, XVI i XVII wieku, z lat 1483 - 1689, a ponadto jeden prawdopodobnie z XVIII wieku (datowany na 1523 rok) oraz dwa późniejsze z przełomu XVIII i XIX wieku (1800 i 1814). Stron niezapisanych jest 10: s. 1 (obecnie zawiera noty biblioteczne z XIX i XX wieku), 10, 22, 28, $32-35,41-42$.

Nieznane jest pierwotne przeznaczenie składki pierwszej (s. 1-12), na kartach której znajdują się głównie wpisy znacznie późniejsze — z XVII wieku oraz dwa z końca XVI stulecia, w dodatku są one wymieszane - zarówno treściowo, jak i chronologicznie. Przeważają wpisy z 1. poł. XVII wieku, dotyczące wyzwoleń uczniów z nauki na czeladnika ${ }^{15}$. Wnioskując na podstawie wpisów najstarszych, można przyjąć, że w pierwotnym założeniu obecna składka druga (s. 13-20) została przeznaczona na statuty cechowe. W tym miejscu trzeba dodać, że dysponujemy pełną treścią statutu cechu kowali i innych rzemiosł, który w późniejszej redakcji z 1493 roku zachował się w oryginalnym dokumencie pergaminowym rady miasta Proszowic ${ }^{16}$. Umożliwia on pogłębienie analizy artykułów cechowych wpisanych do księgi.

Składka trzecia (s. 21-48) prawdopodobnie miała zawierać wykaz członków bractwa cechowego. W efekcie jednak, oprócz krótkiego wykazu, zawierającego zaledwie 12 osób, są w niej różne tematycznie wpisy (m.in. sprawy sporne rozpatrywane przez sąd cechowy z XVII wieku, rozliczenia mistrzów wobec cechu oraz opłaty wnoszone przez uczniów), a przy tym w zasadzie najpóźniejsze $-\mathrm{z}$ XVI-XVII wieku ${ }^{17}$ oraz dwa z końca XVIII i początku XIX wieku ${ }^{18}$. Trzeba jednak zaznaczyć, że na kartach tej właśnie składki, w kilku miejscach, wpisywane były osoby przyjęte do cechu w XVI-XIX

${ }^{15}$ BJ, rkps 1111, s. 2-12 (s. 1 niezapisana). W składce pierwszej najwięcej wpisów dotyczy wyzwoleń uczniów z nauki na czeladnika z lat 1615-1629, 1635-1636, 1638, 1641 (w sumie 26 wpisów). Ponadto zawiera ona obszerny inwentarz wyposażenia liturgicznego kaplicy i ołtarza cechowego z 1575 r., potwierdzenie odbioru długu z 1689 r., dwa formularze przysięgi wymaganej od nowo przyjmowanego brata cechowego (jeden datowany na 1598 r.), dwa wpisy złożonych przysiąg przez dwóch nowych braci z 1627 r., zeznanie świadków potwierdzających prawe pochodzenie kandydata do cechu z 1638 r. Zob. też opis rękopisu: Catalogus..., s. 397.

16 Statut cechu różnych rzemiosł, z główną rolą kowali i powroźników, został potwierdzony w dokumencie wydanym wspólnie przez plebana proszowickiego i radę miasta Proszowic z 26 lipca 1493 r. Oryginał pergaminowy tego dyplomu, bez pieczęci, z dziurkami po sznurku jednej pieczęci, o wymiarach: $616 \times 664+62 \mathrm{~mm}$, jest przechowywany w Muzeum Ziemi Miechowskiej, sygn. MZM/P/3 (pergamin po konserwacji, rozprostowany). O dokumencie wspomina F. Kiryk: Dzieje Proszowic..., s. 37; Tenże: Miasto średniowieczne..., s. 57, przyp. 46. Autor niniejszego artykułu przygotowuje edycję krytyczną tego dokumentu.

${ }^{17}$ Najpóźniejszy wpis z XVII w. jest datowany na 1672 r. — zawiera przysięgę złożoną przez dwóch rzemieślników nowo przyjmowanych do cechu (BJ, rkps 1111, s. 40).

${ }^{18}$ Wpisy najpóźniejsze są datowane na 1800 i 1814 r. — oba dotyczą wpisania ucznia do cechu. Por. tamże, s. 40, 44. 
wieku, czasami nawet $\mathrm{w}$ formie listy członków ${ }^{19}$. W składce trzeciej jest też jeden wpis podejrzany co do treści, sporządzony w języku polskim, najpewniej w XVIII wieku, na co wskazuje pismo. Zawiera on rzekomo treść dokumentu z 1 lipca 1523 roku, potwierdzonego jakoby przez arcybiskupa Jana, spisanego zaś ręką pisarza Jana z Wielopola. Określono w nim i ujęto w tabeli stawki, jakie miały być oddawane przez przedstawicieli poszczególnych rzemiosł - zarówno przez uczniów i czeladników, jak i przez mistrzów różnych rzemiosł. Cały wpis jest opatrzony podpisem pisarza Jana Żurowskiego. Dotąd nie zwrócono uwagi na wątpliwą autentyczność tego tekstu ${ }^{20}$. Wygląda on na kompilację, sporządzoną z wykorzystaniem autentycznych dokumentów. Wskazuje na to zwłaszcza wzmianka o pisarzu miejskim Janie z Wielopola, bakałarzu sztuk i nauczycielu szkoły parafialnej, który rzekomo w 1523 roku miał spisać dokument. W rzeczywistości był on pisarzem miejskim, najpewniej w latach $1491-1496^{21}$. Jego podpis widnieje na dokumencie rady miasta potwierdzającym statut cechu kowali i powroźników z 1493 roku, z adnotacją o zredagowaniu przez niego tegoż tekstu. Ponieważ dyplom przechowywano w cechu kowalskim, z łatwością zapożyczono oryginalną subskrypcję pisarza i w tłumaczeniu na język polski wpisano ją dla uwiarygodnienia spreparowanego wpisu' ${ }^{22}$.

19 Tamże, s. 39 (rzemieślnicy zrzeszeni w cechu z 1635 r.), 40 (wykazy członków z 1672 r., przyjęci do cechu w 1814 r.), 43 (1646 r.), 44 (1800 r.), 48 (1598 r.); zob. też Catalogus..., s. 398.

${ }^{20}$ BJ, rkps 111, s. 29-31. Podobizna stron zawierających ten wpis została opublikowana w monografii miasta, a autorzy rozdziałów dotyczących zarówno dziejów średniowiecznych, jak i nowożytnych uznali bez większych wątpliwości wiarygodność tego tekstu. Por. F. Kiryk: Miasto średniowieczne..., s. 57; F. Leśniak: W okresie Polski szlacheckiej..., s. 177-178, 187, 247. Podobnie autorzy opisu katalogowego nie dostrzegli nieadekwatności pisma do 1523 r., a ponadto połączyli w jedną osobę Jana z Wielopola i Jana Żurowskiego, choć jednocześnie właściwie wskazali drogę edukacji tego pierwszego (Catalogus..., s. 398).

${ }^{21}$ Jan Wielopolski, syn Macieja de Wyelopole (miejscowość niezidentyfikowana), wpisany na Uniwersytet Krakowski w 1477 r., w 1488 r. został wypromowany na bakałarza sztuk (Metryka Uniwersytetu Krakowskiego z lat 1400-1508. Wyd. A. Gąsiorowski, T. Jurek, I. Skierska, przy współpr. R. Grzesika. Kraków 2004, nr 77e/123; Najstarsza księga promocji Wydziału Sztuk Uniwersytetu Krakowskiego z lat 1402-1541. Wyd. A. Gąsiorowski, T. Jurek, I. Skierska. Warszawa 2011, s. 250, nr 88/70). Wpisy jego ręki w księgach ławniczych Proszowic są od 26 sierpnia 1491 do 8 lipca 1496 r. (ANKr, 29/121/0: Variae civitates et villae, sygn. 29/121/0/-/167, s. 270-367; 29/121/0/-/160, s. 485-544). Jest to ręka, którą w „Wykazie rąk pisarskich sporządzających wpisy do prawa miejskiego w Proszowicach" oznaczono numerem 21 (K. Nabiałek: Registrum hominum ius civile susceptorum. Rejestr przyjęć do prawa miejskiego Proszowic z XV wieku. „Średniowiecze Polskie i Powszechne" 2018, T. 10 (14), s. 155). W innym tomie ksiąg ławniczych wpisy za 1523 r. z pewnością zostały sporządzone inną ręką (ANKr, Variae civitates et villae, sygn. 29/121/0/-/161, s. 136-140).

${ }^{22}$ Pod zakładką oryginalnego dyplomu rady Proszowic z 1493 r., zatwierdzającego statut cechu kowali i powroźników, jest następująca nota: „Johannes de Vyelepolye arcium liberalium baccalarius, protunc rector scole et notarius, hoc privilegium confecit et manu propria scripsit" 
Jakikolwiek był pierwotny zamysł twórców księgi, wydaje się, że nie został zrealizowany. Brak bowiem wyraźnego porządku chronologicznego i tematycznego również w składkach zawierających średniowieczne teksty: w drugiej i trzeciej. Wypada zauważyć, że wymieszanie treści i niekonsekwencja chronologiczna przy wprowadzaniu wpisów są zresztą dość powszechne w księgach cechowych różnych miast ${ }^{23}$.

Z najstarszego wpisu (wyróżnionego większym modułem, w formie nagłówkowej) dowiadujemy się, że jest to księga korporacji kowali (liber fraternitatis fabrilis). Założyli ją mistrzowie kowale i jeden ślusarz. Wymienione zostały ich nazwiska: Jan Durszlak, Marcin Jeziorkowski, Mikołaj Tuszyński, Jan Oczko, Piotr Sraba, Jan Czeczot (ślusarz). Wyprzedzając nieco tok wywodu, dodam, że żadnej z tych osób nie ma w wykazie członków bractwa, datowanym również na 1483 rok. $Z$ treści wpisu wynika, że założono tę księgę w ostatnim tygodniu tegoż roku (po Bożym Narodzeniu), w domu kowala Jana, zapewne Durszlaka, który, jak można przypuszczać, pełnił funkcję cechmistrza tej korporacji ${ }^{24}$. Po nagłówku wpisano kursywą gotycką, tą samą ręką, a więc najpewniej w tym samym czasie, statut zrzeszenia, a ściślej siedem punktów ${ }^{25}$.

W pierwszym artykule statutu znajduje się informacja dotycząca zasad przyjmowania nowych mistrzów. Punkt drugi nakazywał braciom cechowym obowiązek uczestnictwa w pogrzebie zmarłego mistrza. Artykuł trzeci dotyczył kar za niestawienie się na zgromadzeniu cechowym po zwołaniu go przez cechmistrza (senior magister) za pomocą znaku, czyli cechy, określonego po polsku jako „czecha" ${ }^{26}$. Termin ten wprost wskazuje na charakter zrzeszenia,

(MZM/P/3); w księdze cechowej podpis ten ma następującą treść: „Jan z Wielopola nauk wyzwolonych bakałarz, natenczas rector albo rządca szkoły i pisarz ten przywiley ręką własną pisał" (BJ, rkps 1111, s. 30-31). Zależność obu tekstów jest niewątpliwa. Można jednak dopuścić, że dla czasu sporządzenia wpisu (XVIII w.) zawarte w nim informacje oddają faktyczny stan rzemiosła zrzeszonego w cechu kowali proszowickich.

${ }^{23}$ Wymieszane chronologicznie wpisy są m.in. w pochodzącej z XV-XVI w. Księdze cechowej złotników krakowskich..., s. 205-206. Podobną praktykę stosowano w księgach późniejszych — m.in. w Wojniczu (Wojnickie księgi cechowe. T. 1: Księgi wpisów cechu wielkiego. Wyd. J. Chumiński, J. Szymański. Wojnicz 1998, s. 6-7).

${ }^{24}$ BJ, rkps 1111, s. 13: „Liber fratrum fraternitatis fabrilis in Proschouicze per eos infrascriptos fratres roboratus per divinam voluntatem admissus et constitutus 1483 per providos viros et magistros huius artificii Johannem fabros $[s]$ Durslak, Martinum Yessyorkowski, Nicolaum Tusynski, Johannem Oczko, Petrum Srabam, Johannem Czÿeczioth serifabrum, in domo Johannis fabri, post festum Nativitatis Domini, anno ut supra”. Por. F. Kiryk: Dzieje Proszowic..., s. 37; Tenże: Miasto średniowieczne..., s. 57-58. W cytatach źródłowych zastosowano zasady według: A. Wolff: Projekt instrukcji wydawniczej dla pisanych źródet historycznych do połowy XVI wieku. St. Źr. 1957, T. 1, s. 157-177.

${ }^{25}$ BJ, rkps 1111, s. 13-15.

26 Stownik staropolski. T. 1: A-Ć. Warszawa 1953-1955, s. 215-216 (Cecha); Stownik polszczyzny XVI wieku. T. 3: By-Cyzyjojanus. Wrocław-Warszawa-Kraków 1968, s. 137 (Cecha). 
czyli cechu, nazywanego tu po łacinie fraternitas ${ }^{27}$. Punkt czwarty odnosił się do sądownictwa cechowego - określono w nim kary przewidziane wobec tych członków cechu, którzy nie będą się podporządkowywać wyrokom cechmistrzów wydanym w sprawach spornych. Artykuł piąty dotyczył kar przewidzianych za naruszanie porządku na zgromadzeniach cechowych - chodziło tu zarówno o kłótnie czy bijatyki, jak i o znieważenia słowne. W punkcie szóstym określono kary dla młodszych braci za nieposłuszeństwo przy organizacji procesji w Boże Ciało i w inne święta. Ostatni, siódmy, artykuł skierowany był do mistrzów rzemieślniczych, którym pod karami pieniężnymi zakazano goszczenia w swoich domach kandydatów na uczniów (discipulus) dłużej niż przez dwa tygodnie.

Treść poszczególnych punktów nie pozostawia wątpliwości, że założyciele księgi tworzyli już w tym czasie $\operatorname{cech}^{28}$. Artykuły te służyły regulacji funkcjonowania organizacji cechowej. Wyraźnie mowa w nich o mistrzach rzemieślniczych oraz o podziale członków zrzeszenia na dwie grupy — starszych i młodszych braci, tj. na mistrzów i czeladników. Wprawdzie w dwóch punktach zawarto informacje dotyczące uczestnictwa braci w nabożeństwach, ale wiadomo, że w cechach rzemieślniczych wspólne praktyki religijne były ważnym i stałym elementem życia wspólnotowego ${ }^{29}$. Wolno uznać, że najprawdopodobniej jest to tylko część statutu, a może tylko jego wstępny projekt. Wszystkie punkty, w mniej lub bardziej zmienionej postaci, zostały powtórzone w zachowanym w całości statucie tego cechu z 1493 roku, który zawiera znacznie więcej innych postanowień. Wówczas kontubernia ta

${ }^{27}$ Łaciński rzeczownik fraternitas może być tłumaczony na język polski zarówno jako 'bractwo', jak i 'cech'. W wypadku cytowanych artykułów kowali oznacza niewątpliwie cech. Por. Słownik łaciny średniowiecznej w Polsce. T. 4: F-H. Red. M. Plezia. Wrocław-Warszawa-Kraków—Gdańsk 1975-1977, kol. 371-372 (Fraternitas); Stownik staropolski..., s. 146 (Bractwo), 215-216 (Cech, Cecha).

${ }^{28}$ F. Kiryk w pierwszym opracowaniu poświęconym Proszowicom nazwał zrzeszenie kowali bractwem rzemieślniczym (Tenże: Dzieje Proszowic..., s. 37). W monografii miasta nie miał już wątpliwości, że był to cech. Historyk ten nie podjął jednak próby ustalenia, kiedy cech powstał i kiedy został poszerzony o powroźników oraz o pojedynczych przedstawicieli rzemiosł metalowych i drzewnych. Zasugerował, że nastąpiło to w 1493 r., gdy wydany został dokument rady zatwierdzający statut, w 1483 r. zaś dyskutowano o tym przyłączeniu, co znalazło odbicie w księdze cechu (Tenże: Miasto średniowieczne..., s. 57-59). Hipoteza ta jednak nie jest przekonywająca, gdyż w treści statutów zawartych w księdze nie ma o tym w ogóle mowy. Wśród starszych cechu są tylko kowale i jeden ślusarz, nie ma zaś innych rzemiosł, a zwłaszcza powroźników, którzy w 1493 r. będą stanowić drugą wiodącą specjalność w cechu.

${ }^{29}$ E. Wiśniowski: Bractwa religijne na ziemiach polskich $w$ średniowieczu. „Roczniki Humanistyczne" 1969, T. 17, z. 2, s. 60; Tenże: Parafie w średniowiecznej Polsce. Struktura i funkcje społeczne. Lublin 2004, s. 195-197; I. Czarciński: Bractwa..., s. 24-26.; Z. Kropidłowski: Samopomoc w korporacjach..., s. 114-117; J. Tandecki: Struktury administracyjne i spoleczne..., s. 75-77; D. Żurek: Przestrzeń i spoleczeństwo Chrzanowa średniowiecznego i nowożytnego. Kraków 2015, s. 236. 
faktycznie przekształciła się ze zrzeszenia jednej głównej profesji w cech równorzędnych rzemiosł kowali, powroźników i innych specjalności, głównie metalowych i drzewnych (ślusarzy, nożowników, mieczników, kotlarzy, stelmachów i kołodziei ${ }^{30}$. Porównanie treści adekwatnych punktów w obu statutach skłania do wniosku, że wpis w księdze stanowi kopię dawniejszego statutu tego cechu, wydanego w 1483 roku, a być może jeszcze wcześniej. Główną przesłanką jest niezbyt precyzyjne brzmienie części tekstu, wynikające prawdopodobnie z przestawienia szyku zdania ${ }^{31}$, a także z pominięcia części wyrazów ${ }^{32}$. Tekst statutów mógł być wpisany do księgi ex post, na co zdaje się wskazywać przypuszczalny czas powstania papieru — przypomnijmy: w przybliżeniu datowany na lata 1488-1491. Bardziej prawdopodobne wydaje się jednak, że papier powstał kilka lat wcześniej, zgodnie z podaną w nagłówku datą założenia księgi (1483). Można również postawić hipotezę, że punkty wpisane do księgi stanowią dopiero wstępny projekt statutu, który był dyskutowany na zebraniu cechowym i na gorąco protokołowany. Tym można byłoby wyjaśnić jego niekompletność. To drugie wytłumaczenie mogłoby świadczyć o tym, że cech dopiero się formował. Wszystkie interpretacje należy jednak traktować jako hipotezy wymagające dowodów na ich potwierdzenie.

${ }^{30} \mathrm{MZM} / \mathrm{P} / 3$ : ,volentes profectum ac utilitatem in fraternitate contubernii alias w »czechu« unius et eiusdem coniunctim variorum seu distinctorum artificiorum horum videlicet fabrorum, funificum, serificum, cutellificum, gladificum, caldarificum, currificum, rothificum noviter erigere, fundare et augmentare, quantum nostra suppetit facultas dare, decrevimus, ut prefata fraternitas horum artificiorum in unum gremium et contubernium indistincte cumulata nostris temporibus...”. O pozycji powroźników świadczą odrębne i podobnej objętości artykuły dotyczące ich rzemiosła, przytoczone w dokumencie po punktach dla kowali.

${ }^{31}$ Punkt 6 statutu wpisany do księgi jest niejasny, niewątpliwie z powodu błędnej składni: „Statuimus, quod tempore Corporis Christi et in festo tocius octave, quod quando senior frater mandaverit candelas iuniori portare ipse recusaverit et in aliis processionibus iuxta ritum ecclesie Proschouiensis, extunc penam reponat mediantem in cisticulam fraternitatis et in omnibus processionibus" (BJ, rkps 1111, s. 14). W dokumencie z 1493 r. układ niemal identycznego tekstu jest zaś logiczny: „Item statuimus, quod tempore Corporis Christi et in festivitate totius octave ac in aliis processionibus iuxta rittum ecclesie huius, quando seniores magistri mandaverint iunioribus candelas portare et ipsi recusaverint, extunc penam quilibet eorum reponat medium grossum in cisticulam fraternitatis" $(\mathrm{MZM} / \mathrm{P} / 3)$.

32 Punkt 4 statutu wpisany do księgi brzmi: „Statuimus, quod quicunque hominum aut inter se fratres coquerulaverint $[s]$ coram seniori magistro ipse esset rebellis et inobediens et senior magister decrevit solucionem, extunc reponat penam magistralem talentum cere in cisticulam fraternitatis si non fecerit solucionem persone" (BJ, rkps 1111, s. 14). Adekwatny punkt w dokumencie z 1493 r. jest znacznie obszerniejszy, a przy tym ułożony włáciwie: „Item statuimus, quod quicumque hominum aut inter se fratres conquerulaverint coram senioribus magistris, aut super aliquem ex fratribus pro debito et seniores magistri decreverint solucionem, si talis sit rebellis et inobediens, extunc reponat penam magistralem talentum cere in ladulam, si hoc non fecerit iuxta decretum, si autem amplius non curaverit, extunc seniores debent eidem artificium postponere tamdiu donec solucionem fecerit persone" (MZM/P/3). 
Funkcjonowanie cechu kowali w chwili założenia księgi w Proszowicach nie ulega więc wątpliwości. Wydaje się, że są przesłanki, by uznać, że przy tym zrzeszeniu zawodowym istniało wówczas też bractwo religijne (bractwo cechowe). W literaturze pojawiały się odmienne poglądy na możliwość istnienia bractw religijnych przy cechach rzemieślniczych, niezależnie od tych zrzeszeń. Zdaniem części badaczy nie było odrębnych stowarzyszeń dewocyjnych przy zawodowych zrzeszeniach rzemieślniczych, a funkcje religijne pełniły same cechy ${ }^{33}$. Nowsze badania w wielu ośrodkach miejskich pokazały jednak, że funkcjonowanie religijnych bractw cechowych, obok samych cechów, było zjawiskiem powszechnym ${ }^{34}$.

Według Stanisława Litaka „bractwa religijne to małe zorganizowane na zasadzie dobrowolności, w pewnym stopniu autonomiczne, erygowane przez władzę kościelną społeczności wiernych obojga płci, wywodzących się z różnych stanów i warstw społecznych, funkcjonujące przy kościołach podległych biskupom lub zakonom i realizujące własne cele publiczno-religijne i społeczne" ${ }^{35}$. Nie można z pewnością stwierdzić, czy funkcjonujące przy cechu bractwo kowali spełniało warunki podane w definicji. Brak źródeł, które pozwoliłyby jednoznacznie rozstrzygnąć tę kwestię. Istnieją jednak dość mocne przesłanki przekonujące, że jednak tak było. Przede wszystkim wskazuje na to wykaz na karcie rozpoczynającej drugą składkę rękopisu, zatytułowany: Fratres unacum sororibus inditi fraternitati fabrili in Proschowicze $1483^{36}$. Edycja tego tekstu stanowi załącznik do niniejszego artykułu (Aneks 1). Tekst podano według zasad zaproponowanych w projekcie instrukcji wydawniczej Adama Wolffa ${ }^{37}$.

33 J. Ptaśnik: Miasta i mieszczaństwo w dawnej Polsce. Wyd. 2. Warszawa 1949, s. 124 125; I. Czarciński: Bractwa..., s. 24-27.

${ }^{34}$ E. Wiśniowski: Bractwa religijne..., s. 60-61; Tenże: Parafie w średniowiecznej Polsce..., s. 195-197; F. Kiryk: Bractwo religijne kowali..., s. 115-123; Tenże: Rzemiosła i organizacje rękodzielnicze..., s. 66-67; J. Tandecki: Struktury administracyjne i spoteczne..., s. 77; E. Wółkiewicz: Kościół i jego wierni. Struktury kościelne i formy pobożności w średniowiecznej Nysie. Kraków 2014, s. 204-205; D. Żurek: Przestrzeń i społeczeństwo Chrzanowa..., s. 228-232; K. Nabiałek: Bractwo klasztoru św. Katarzyny z Góry Synaj w miastach polskich (Żarnowiec, Sienno, Wieluń). W: Felix indiget amicis. Studia z dziejów kultury duchowej i intelektualnej średniowiecza ofiarowane Profesorowi Krzysztofowi Ożogowi. Red. W. Świeboda, M. Zdanek. Kraków 2016, s. 180-188.

${ }^{35}$ S. Litak: Bractwa religijne w Polsce przedrozbiorowej XIII-XVIII wiek. Rozwój i problematyka. Prz. Hist. 1997, T. 88, z. 3/4, s. 500-501.

${ }^{36}$ BJ, rkps 1111, s. 21. Zob. też fot. 2 i Aneks 1. Istniała praktyka sporządzania list członków konfraterni w księgach brackich. Np. z 1481 r. zachował się spis braci i sióstr bractwa religijnego pw. NMP przy kościele Mariackim w Krakowie; nie było to jednak bractwo cechowe (H. Zaremska: Bractwa..., s. 67). Bractwo kowali w Bochni prowadziło odrębną księgę przyjęć, do której wpisano w sumie 423 członków z lat 1462-1559 (F. Kiryk: Bractwo religijne kowali..., s. 115-118).

${ }^{37}$ A. Wolff: Projekt instrukcji wydawniczej dla pisanych źródeł historycznych... — zob. przyp. 24. 
Ponieważ jego zawartość stanowią niemal wyłącznie nazwy osobowe i geograficzne, należy zaznaczyć, że oddano ich zapis zgodnie z lekcją oryginału. Wyjątek dotyczy zastosowania dla wszystkich nazw własnych (imiona, nazwiska, przezwiska, nazwy miejscowe) pisowni dużą literą, zgodnie z obecnymi zasadami ortografii języka polskiego. Wprowadzono numerację osób, której $\mathrm{w}$ oryginale brak. Ponieważ aneks ten pełni funkcję pomocniczą wobec tekstu, identyfikacji osób i miejscowości dokonano w tekście głównym.

Wykaz ten zawiera listę osób, z których przynajmniej część z pewnością nie należała do cechu kowali. Ponadto nagłówek zapowiadał, że członkami tej korporacji miały być również kobiety. Choć żadnej siostry w wykazie nie wymieniono, to już sam zamiar wyklucza tu organizację cechową. A zatem określenie fraternitas oznacza w tym wypadku bractwo. Lista najpewniej nie została dokończona, gdyż, wbrew zapowiedzi, znaleźli się na niej tylko mężczyźni, a w dodatku nie jest ich wielu (12 osób) ${ }^{38}$. Ponadto jest to zapewne pierwsza grupa członków stowarzyszenia, obejmująca mieszkańców miasta Proszowic, jak wskazuje nota dodana nad nazwiskami ${ }^{39}$. Wolno przyjąć, że do wykazu miały zostać też wpisane osoby spoza miasta, co było praktykowane $\mathrm{w}$ bractwach religijnych ${ }^{40}$. Listę braci otwierają przedstawiciele elity miejskiej: ówczesny wójt - Marcin Rudnik ${ }^{41}$, oraz jeden z najzamożniejszych podówczas mieszczan, handlarz solą i wieloletni rajca - Klemens Słonko ${ }^{42}$. W 1496 roku ufundował on nowy ołtarz w kościele parafialnym, który zapewne od jego imienia otrzymał wezwanie św. Klemensa. Prawdopodobnie fundacja ta była dokonana $\mathrm{z}$ myślą o praktykach religijnych bractwa kowali. Nie może być przypadku w tym, że w XVI wieku to konfraternia kowali właśnie opiekowała się kaplicą św. Klemensa ${ }^{43}$. Można więc założyć, że było

${ }^{38}$ BJ, rkps 1111, s. 21 = Aneks 1. W późniejszych wpisach nie ma już wzmianki o członkach bractwa, za to kilkukrotnie wymienieni zostali rzemieślnicy należący do cechu lub nowo przyjęci do niego. Zob. przyp. 19.

39 Wykaz osób zaczyna się od noty: „In civitate habitantes” — Aneks 1.

${ }^{40}$ Do jednego z bractw krakowskich przyjmowano mieszkańców przedmieść (H. Zaremska: Bractwa..., s. 78 - 79). W Bochni członkami pokrewnego bractwa kowali byli m.in. funkcjonariusze salin bocheńskich (F. Kiryk: Bractwo religijne kowali..., s. 118-119). Do bractwa krawców Proszowic wpisano liczne osoby z wsi położonych koło miasta — o czym piszę dalej (zob. podrozdział Księga bractwa i cechu krawców).

${ }^{41}$ Aneks 1, nr 1. Marcin Rudnik był wójtem sądowym w latach 1482-1490; wcześniej, w latach 1477-1480, był rajca (ANKr, 29/121/0: Variae civitates et villae, sygn. 29/121/0/-/160, s. $103,112,126,130,172,184,195,209,217,227,257-457)$.

42 Aneks 1, nr 2; F. Kiryk: Miasto średniowieczne..., s. 77-78.

${ }^{43}$ AGAD, MK 17, k. 136v-137. Trudno się zgodzić z domniemaniem F. Kiryka, że ołtarzem, którego fundację sfinansował Klemens Słonko, był ołtarz główny lub ołtarz pw. św. Anny (F. Kiryk: Miasto średniowieczne..., s. 77, 81). Za wezwaniem św. Klemensa dla tej fundacji przemawia właśnie owo stosunkowo rzadkie patrocinium (w wybranych czterech dekanatach z różnych części diecezji krakowskiej, liczących 60 parafii, według danych z lat 1766-1782 B. Kumor nie stwierdził żadnego ołtarza pw. św. Klemensa), członkostwo Słonki 
tak od czasu jej erekcji dokonanej dzięki środkom wyłożonym przez jednego ze współbraci.

O wysokim prestiżu tego zrzeszenia poniekąd świadczy też obecność wśród członków trzech piwowarów ${ }^{44}$. Do takiego wniosku skłania fakt, że ta gałąź produkcyjna była $\mathrm{w}$ mieście bardzo dobrze rozwinięta i miała przypuszczalnie długą tradycję, a piwo proszowickie cieszyło się dobrą opinią w Krakowie ${ }^{45}$. Jeden $\mathrm{z}$ wpisanych był szewcem (Antoni), a być może z tym rzemiosłem można wiązać trzeciego na liście Sówkę ${ }^{46}$. Przy trzech osobach — dwóch kowalach (Pawle i Janie) i ślusarzu Leonardzie - dodano przymiotnik mortuus $^{47}$. Zapewne byli to zmarli mistrzowie cechu kowali, których wpisano pośmiertnie, najpewniej w celu zapewnienia im modlitw za zbawienie duszy. Być może wykaz miał być po części rejestrem zmarłych członków cechu i bractwa, na wzór innych korporacji ${ }^{48}$. Praktykę zapisywania do bractwa sporej grupy osób nieżyjących, najczęściej krewnych, członków korporacji, stwierdził w bocheńskim bractwie kowali F. Kiryk ${ }^{49}$. Wykaz w Proszowicach kończy się na kapłanie bractwa Janie Pręchniczu (Pranchnicz presbiter fraternitatis), którego obecność również wskazuje na religijną funkcję zrzeszenia ${ }^{50}$.

Inną przesłanką świadczącą o funkcjonowaniu bractwa cechowego kowali w XV wieku jest wystąpienie wraz z rajcami w roli wystawcy dokumentu z 1493 roku, potwierdzającego statut tegoż cechu, Jana, plebana w Proszowi$\mathrm{cach}^{51}$. Wskazuje to na istnienie związku tej korporacji z kościołem parafialnym. Z kolei potwierdzenie funkcjonowania bractwa kowali w XVI wieku

w bractwie kowali oraz poświadczony w XVI w. związek tej konfraterni z kaplicą pw. św. Klemensa właśnie (zob. przyp. 52-53). W inwentarzu z 1575 r., wpisanym do księgi, jest wprawdzie informacja o kaplicy i ołtarzu cechu kowali, jednak nie podano jego wezwania. Por. BJ, rkps 1111, s. 7; B. Kumor: Dzieje diecezji krakowskiej do roku 1795. T. 4. Kraków 2002, s. $506,510,565-569$.

${ }^{44}$ Przy trzech osobach: Pawle, Kuli i Mikołaju, dodano określenie: braxator cervisie (Aneks 1, nr 4, 6, 10).

${ }^{45}$ F. Kiryk: Miasto średniowieczne..., s. 59-60.

46 Aneks 1, nr 3, 11. Sówka być może był synem Jana Sowy (Schowa), cechmistrza szewców, wzmiankowanego w 1447 r. Z wyjątkiem nazwiska brak jednak innych podstaw do identyfikacji. Por. ANKr, 29/121/0: Variae civitates et villae, sygn. 29/121/0/-/166, s. 190; F. Kiryk: Miasto średniowieczne..., s. 57.

${ }^{47}$ Aneks 1, nr 7, 8, 9.

48 J. Rajman: Rajcy krakowscy $i$ członkowie ich rodzin $w$ księdze zmarlych bractwa Najświętszej Marii Panny w Krakowie (połowa XIV—koniec XVI wieku). „Średniowiecze Polskie i Powszechne" 2015, T. 7 (11), s. 45-61.

${ }^{49}$ F. Kiryk: Bractwo religijne kowali..., s. 117.

${ }^{50}$ Aneks 1, nr 12.

${ }^{51}$ Był to najpewniej Jan z Oleśnicy w ziemi sandomierskiej, magister sztuk, poświadczony jako pleban proszowicki od 1489 r. do prawdopodobnie 1495 lub 1496 r. (zmarł przed 26 listopada 1496 r.). Por. MZM/P/3; ANKr, 29/121/0: Variae civitates et villae, sygn. 29/121/ 0/-/167, s. 339, 374; J. Wiśniewski: Dekanat miechowski..., s. 312; Metryka Uniwersytetu Krakowskiego..., $\mathrm{nr}$ 59h/182; Najstarsza księga promocji..., $\mathrm{nr}$ 62/41, 65/5. 
znajduje się w wizytacji biskupiej z 1595 roku. Stwierdzono tam, że bractwo kowali (fraternitas ferrifabrorum) zostało ufundowane przy kościele parafialnym, a jego statuty (ordinationes seu statuta) zatwierdził arcybiskup gnieźnieński $\mathrm{Jan}^{52}$. Nie wiadomo, o którego arcybiskupa chodziło, ale można się domyślać, że o jednego z biskupów krakowskich, który awansował na metropolitę. Zatwierdzenie statutów przez zwierzchnika religijnego i odnotowanie ich w wizytacji biskupiej świadczy o religijnym charakterze zrzeszenia. Do obowiązków bractwa należało dostarczanie wosku do kaplicy św. Klemensa w kościele parafialnym, co pozwala dokładnie zlokalizować miejsce sprawowania praktyk religijnych przez współbraci ${ }^{53}$.

Bractwo cechowe kowali powstało najpewniej jako drugie w mieście, po bractwie literackim pw. Najświętszej Panny Marii54. Nie ustalono dotąd początków tego najstarszego zrzeszenia. W monografii miasta przyjęto, że ufundowano je w XVI wieku ${ }^{55}$, choć jednocześnie F. Kiryk wspomina o fundacji na rzecz „bractwa św. Marii”, dokonanej w testamencie przez Jana Powroźnika i jego małżonkę, a potwierdzonej w $1505 \mathrm{roku}^{56}$. Nie ulega jednak wątpliwości, że istniało ono już w latach 30 . XV wieku. W księgach miejskich bractwo literackie jest wzmiankowane w 1435, 1436, 1448 i 1496 roku $^{57}$. Jego wezwanie skłania do przypuszczenia, że mogło ono powstać po erygowaniu w 1418 roku w kościele parafialnym altarii pw. NMP i św. św. Piotra i Pawła ${ }^{58}$. Bractwa literackie grupowały ludzi potrafiących pisać, mogących recytować i śpiewać

${ }^{52}$ AMetrKra, Acta Visitaciones capituli, sygn. AVCap. 65, k. 250.

53 Tamże.

${ }^{54}$ Tak wynika z wizytacji diecezji krakowskiej z 1595 r. Wyraźnie odróżniono tam bractwo kowali od bractwa literackiego, a jednocześnie fraternitas ferrifabrorum wymieniono jako pierwsze spośród bractw cechowych. Por. tamże, k. 250-250v.

${ }^{55}$ F. Leśniak, przyjmując ściśle przekaz z wizytacji biskupiej z 1595 r., podał, że bractwo literackie w Proszowicach zostało erygowane w 1565 r. (Tenże: W okresie Polski szlacheckiej..., s. 237). Nie zwrócił przy tym uwagi na ewidentną nieścisłość przekazu źródłowego, jakoby erygował to bractwo w 1565 r. biskup krakowski Jan — wiadomo, że w tym roku zwierzchnictwo nad diecezją krakowską sprawował Filip Padniewski. Ponadto w księdze czynności biskupich z okresu jego pontyfikatu brak adekwatnego wpisu (AMetrKra, Acta episcopalia Cracoviensia (dalej: AEp.) 29). Można raczej przyjąć, że doszło do błędu w zapisie daty i chodziło o 1465 r., gdy biskupem był Jan Lutek z Brzezia. Niestety tom akt jego czynności biskupich, zresztą najstarszy z zachowanych w ogóle, zaczyna się wpisami od 1466 r. W tomie tym brak dokumentu dotyczącego bractw w Proszowicach (AMetrKra, AEp. 1).

${ }^{56}$ F. Kiryk: Miasto średniowieczne..., s. 77. Legat testamentowy Jana Powroźnika i jego małżonki został wpisany do księgi ławniczej już w 1496 r. Por. ANKr, 29/121/0: Variae civitates et villae, sygn. 29/121/0/-/160, s. 541-542. Regest testamentu: Testamenty z ksiag sadowych matych miast polskich do 1525 roku. Oprac. A. Bartoszewicz, K. Mrozowski, M. Radomski, K. Warda. Red. A. Bartoszewicz. Warszawa 2017, s. 104, nr 357 (z datą 1498).

57 ANKr, 29/121/0: Variae civitates et villae, sygn. 29/121/0/-/166, s. 24, 200; sygn. 29/121/0/-/281, s. 256; sygn. 29/121/0/-/160, s. 541-542.

${ }^{58}$ F. Kiryk: Miasto średniowieczne..., s. 80, 82. 
psalmy, i najczęściej miały wezwania maryjne ${ }^{59}$. Nie były one związane z konkretnym cechem i można powiedzieć, że miały zasięg ogólnomiejski, albo inaczej - ogólnospołeczny. Dowodzi tego choćby wspomniana już fundacja pobożna bogatego mieszczanina Jana Powroźnika, który w testamencie dokonał zapisu dla konfraterni literackiej właśnie, a nie na rzecz bractwa cechu kowali i powroźników, w którym był jednym z mistrzów ${ }^{60}$.

Przytoczone argumenty pozwalają, jak się wydaje, uznać, że założona w latach 80. XV wieku księga powstała w związku z działalnością w Proszowicach zarówno cechu kowali, jak i związanego z nim bractwa religijnego.

\section{Księga bractwa i cechu krawców}

Drugi średniowieczny rękopis zawierający akta proszowickiego zrzeszenia rzemieślniczego zachował się wśród dokumentacji gromadzonej przy kościele parafialnym w tym mieście ${ }^{61}$. Dotyczy on krawców. Jest to sześć kart o wymiarach $11 \times 33 \mathrm{~cm}$ (format dutki), które stanowią oryginalną składkę papierową $3+3$, z wyraźnym ściegiem w środku (między s. 22 a 23), wzmocnionym pergaminową zszywką (zapisaną pismem z przełomu XIV i XV wieku) ${ }^{62}$. Ze względu na budowę składki można $\mathrm{z}$ dużym prawdopodobieństwem uznać, że jest to tylko część akt korporacji proszowickich krawców, najpewniej obejmująca najstarsze wpisy. Układ chronologiczny, choć też nieco zaburzony, zasadniczo jest prawidłowy. Najstarsze datowane wpisy pochodzą z 1535 roku, a najpóźniejsze z przełomu XVII i XVIII wieku (lata 1700-1701). Najliczniejszymi tematycznie wpisami są zwolnienia czeladników z obowiązków względem cechu za naukę zawodu ${ }^{63}$.

Wcześniejszy tekst, w formie wykazu osób, został sporządzony jeszcze pod koniec $\mathrm{XV}$ wieku ${ }^{64}$. Na takie datowanie z jednej strony pozwala późnogotycki

${ }^{59}$ E. Wiśniowski: Bractwa religijne..., s. 56-57.

${ }^{60}$ Jan funifex był jednym z mistrzów podpisanych pod statutem połączonego cechu kowali i powroźników, a jednocześnie jako rajca rezydujący wydawał dokument zatwierdzający te artykuły. Por. MZM/P/3.

${ }^{61}$ Cała jednostka aktowa to poszyt połączony sznurkiem konopnym, liczący 98 kart, zawierający różne dokumenty dotyczące Proszowic, głównie związane z parafią, zasadniczo z XVI-XVIII w. (ADK, Akta parafialne II, sygn. IIPP-XVI/1).

${ }^{62}$ Tamże, k. $20-25$.

${ }_{63}$ Najpełniejszy formularz ma wpis z 1545 r. Por. tamże, k. 24v.

${ }^{64} \mathrm{Na}$ stronie rozpoczynającej listę osób ręką prawdopodobnie z XX w. sporządzono atramentem notę: „to są Proszowice z 15 wieku” (tamże, k. 20). 
kształt liter, a z drugiej - czas powstania papieru. Zachowany znak wodny na k. 20 oraz po części na k. 22 i 23 jest identyczny ze znakiem z papieru księgi cechu kowali Proszowic, datowanego na 1488 rok, względnie w przybliżeniu na lata 1488-1491. Również zidentyfikowane osoby występujące na tych kartach poświadczone są w źródłach z lat 80. i 90. XV wieku. Wykaz ten został wydany jako dodatek do niniejszego artykułu (Aneks 2$)^{65}$. Opracowano go według takich samych zasad jak Aneks 1.

Wydaje mi się bardzo prawdopodobne, że prezentowana tu składka stanowiła część zaginionej księgi korporacji rzemieślniczej, która była znana ks. J. Wiśniewskiemu. Historyk ten stwierdził wprawdzie, że była to księga cechowa szewców (,szwiecka”) ${ }^{66}$, ale można dopuścić pomyłkę w odczycie nazwy rzemiosła - sutorum zamiast sartorum. Za powiązaniem tego rękopisu z krawcami zdaje się przemawiać też pewien ważny szczegół. Z przytoczonego przez ks. Wiśniewskiego wpisu początkowego wynika, że oddano temu zrzeszeniu w opiekę ołtarz św. Krzyża w kościele parafialnym ${ }^{67}$. Wiadomo z wizytacji biskupiej, że w XVI wieku to właśnie krawcy opiekowali się ołtarzem św. Krzyża, szewcy zaś ołtarzem wielkim ${ }^{68}$. Nie bez znaczenia jest data założenia księgi — 1489 rok — wpisująca się w orientacyjne datowanie zachowanej składki. Nie można wykluczyć, że brakuje tylko zewnętrznych kart składki, m.in. tej z rokiem 1489, którą zacytował ks. Wiśniewski. Zachowana składka zaczyna się od listy nazwisk, ale pozbawionej nagłówka. Bez dotarcia do zaginionej księgi nie da się oczywiście rozstrzygnąć, czy domysł ten jest słuszny.

Nie ma wątpliwości, że odnaleziona składka jest fragmentem akt korporacji krawców proszowickich. Zasadne jest jednak pytanie, jaki był charakter tego zrzeszenia w chwili założenia księgi. O ile od wpisu z 1535 roku była to z pewnością dokumentacja cechu rzemieślniczego, o tyle najstarsze partie tekstu nie dają jednoznacznej możliwości interpretacyjnej. Zawierają one bowiem wykaz członków fraternitatis sartorum, jak można się domyślać z not przy kilku wpisach ${ }^{69}$. Długa lista osób, obecność na niej kobiet (16) oraz niewątpliwe zróżnicowanie społeczne i zawodowe przekonują, że mamy tu do

${ }^{65}$ Zdjęcie prezentujące fragment kart tego rękopisu (k. 20v-21) zob. fot. 3.

${ }^{66}$ J. Wiśniewski: Dekanat miechowski..., s. 312-313.

67 Tamże, s. 187, 312-313. Według opublikowanego przez ks. J. Wiśniewskiego wpisu, z tytułu oddania ołtarza Jan starszy tego zrzeszenia oraz jego członkowie zobowiązali się do sprawowania przy ołtarzu św. Krzyża na własny koszt jednej mszy świętej w miesiącu (co 4 tygodnie) za wszystkich zmarłych.

${ }^{68}$ AMetrKra, sygn. AVCap. 65, k. 250v.

${ }^{69} \mathrm{~W}$ wykazie w zasadzie tylko trzykrotnie pojawia się nazwa korporacji — przy wpisie Stanisława Śródki, rozpoczynającym nową stronę rękopisu: suscepit fraternitatem sartorum; podobnie w dwóch końcowych wpisach, dotyczących kramarza Klimka Soboczskiego i miecznika, stwierdzono przy każdym z nich: suscepit fraternitatem cum sartoribus (ADK, Akta parafialne II, sygn. IIPP-XVI/1, k. 21, 21v = Aneks 2, nr 45, 79, 81). 
czynienia z rejestrem bractwa religijnego krawców. Część z wpisanych, jak można wnioskować z określeń, zajmowała się inną działalnością niż krawiectwo $^{70}$. Spora grupa osób wreszcie pochodziła spoza miasta - o czym dalej. Bez dodatkowych źródeł nie ma jednak możliwości rozstrzygnięcia, czy istniał w tym czasie również cech krawiecki, czy też bractwo to funkcjonowało samoistnie. Zwraca uwagę bardzo długa lista członków tego zrzeszenia, w której wymieniono w sumie 81 osób, choć być może niektórych wpisano do wykazu więcej niż raz ${ }^{71}$. Wpisy sporządzono prawdopodobnie pięcioma rękami. Najwięcej - 44 osoby — wpisano ręką pierwszą (Aneks 2, nr 1-44). Drugą ręką wprowadzono kolejne 34 osoby (Aneks 2, nr 45-78). Ostatnie trzy wpisy to dzieło trzech różnych rąk (Aneks 2, nr 79-81). Można przypuszczać, że 44 osoby wymienione we wpisach ręki pierwszej były członkami bractwa w tym samym czasie. Część osób w wykazie została skreślona, co można interpretować dwojako - albo zrezygnowały z członkostwa, albo byli to zmarli członkowie korporacji.

Niestety spis członków bractwa nie dostarcza informacji o warunkach, jakie powinien spełniać kandydat, i o tym, jakie powinności względem zrzeszenia winien realizować ${ }^{72}$. Tylko przy trzech wpisach pojawiły się noty, które pozwalają uznać, że takie wymogi jednak stawiano. Dwukrotnie stwierdzono, że członkowie nie zrobili dla konfraterni nic, a w jednym wypadku dodano, że nie wniesiono też opłaty ${ }^{73}$. Tylko w jednym wpisie zaznaczono, że przyjęty do bractwa zapłacił 2 grosze ${ }^{74}$.

Niektóre $\mathrm{z}$ osób wymienionych $\mathrm{w}$ wykazie udało się zidentyfikować. Coczelya (Aneks 2, nr 5) to prawdopodobnie Grzegorz Kocieła — rajca (1476), ławnik (1474 —1475) i długoletni wójt sądowy (1478 — 1479, 1481, 1490—1492,

${ }^{70} \mathrm{~W}$ wykazie są wymienieni: piekarze (pistores) - Błażej i Tomasz, prawdopodobnie rzeźnik - Rrzaycza in maccelis, kramarz - Soboczski, miecznik (gladiator) (tamże, k. 20, 20v, 21v; Aneks 2, nr 21, 38, 60, 79, 81). Szczególnie zaskakuje przystąpienie do bractwa krawców miecznika, skoro rzemieślnicy wyrabiający miecze (gladifices) zgodnie ze statutem z 1493 r. zostali włączeni do cechu kowali i powroźników (MZM/P/3), a przy cechu najpewniej było też i bractwo (zob. część Księga cechu kowali i innych rzemiost).

71 Jest możliwe, że niektóre osoby wpisano dwukrotnie, choć nie ma pewności. Mogły to być podobnie brzmiące nazwiska lub przezwiska. Na pozycjach 3 i 48 wykazu zanotowano: Szilina i Zylyna; na pozycjach 11 i 64 - Mirzwa i Myrzwa; na pozycjach 18 i 74 - Martinus Mloczek i Martinus tritulator; na pozycjach 26 i 76 - Swyatek de Laganow i Swÿathek (w grupie villani). Por. Aneks 2.

${ }^{72}$ Szczegółowo na podstawie analizy księgi brackiej kowali z Bochni przedstawił te powinności F. Kiryk. Tam podstawowym warunkiem przyjęcia do bractwa było wniesienie opłaty wpisowej, a później też opłat kwartalnych. Czasami można było zamienić świadczenia finansowe na naturalia lub pewne posługi na rzecz korporacji. Por. F. Kiryk: Bractwo religijne kowali..., s. 118-119.

73 Aneks 2, nr 45-46.

${ }^{74}$ Aneks 2, nr 80. 
1493-1495) w Proszowicach ${ }^{75}$. Nosczina (Aneks 2, nr 22) — mieszczka Anna Nosczyna w 1474 roku potwierdziła przed sądem ławniczym odbiór należności za sprzedany dom $^{76}$. Nobilis Stanislaus Maslowsky (Aneks 2, nr 24) to prawdopodobnie Stanisław Masłowski, dziedzic dwóch wsi w sąsiedztwie Proszowic Górki w parafii Koniusza (dziś Górka Jaklińska - $3 \mathrm{~km}$ od Proszowic na południowy zachód) i Wierzbna, poświadczony w latach 1480—149677. Swyatek de Laganow (Aneks 2, nr 26) to najpewniej kmieć Świątek z Łaganowa (wieś oddalona od Proszowic o $2 \mathrm{~km}$ na południowy zachód), występujący w latach 1489-1496 ${ }^{78}$. Jacobus de Gnyasdouicze (Aneks 2, nr 28) jest być może tożsamy ze szlachcicem Jakubem Gbelskim z wsi Gniazdowice (dziś część Makocic, ok. $3 \mathrm{~km}$ na północny zachód od Proszowic), zmarłym przed 1503 rokiem, choć mogło tu chodzić o nieznanego skądinąd kmiecia w tej $\mathrm{wsi}^{79}$. Nobilis Laganowsky Johannes (Aneks 2, nr 29) to zapewne Jan Sambor Łaganowski (drugi) herbu Nowina, dziedzic Łaganowa, poświadczony w latach $1470-1497^{80}$. Marszalek (Aneks 2, nr 35) to być może Jakub Marszałek, przyjęty do prawa miejskiego Proszowic pod koniec XV wieku (w latach 80. lub 90. XV stulecia) ${ }^{81}$. Srothka Stanislaus (Aneks 2, nr 45) jest zapewne tożsamy z młynarzem Stanisławem Śródką, poświadczonym w latach 1497-1500 ${ }^{82}$. Spyk Stanislaus (Aneks 2, nr 46) był to mieszczanin proszowicki, wzmiankowany w 1500 roku $^{83}$. Rosna (Aneks 2, nr 49) to najpewniej mieszczka proszowicka Agnieszka Rosna (Roszna), wzmiankowana w 1499 roku wraz ze swoim pasierbem Maciejem Rosznym ${ }^{84}$. Gawlova (Aneks 2, nr 55) to prawdopodobnie mieszczka proszowicka Katarzyna Gawłowa, wzmiankowana w 1497 roku $^{85}$. Cropak (Aneks 2, nr 70) to zapewne Andrzej Kropak - ławnik proszowicki w latach 1492 - 1495, względnie Szczepan Kropak, mieszczanin wzmiankowany w 1496 roku $^{86}$. W wykazie wydzielono też grupkę pięciu mężczyzn, których wpisy opatrzono nagłówkiem: Item villani. Choć nikogo z nich nie udało mi się

75 ANKr, 29/121/0: Variae civitates et villae, sygn. 29/121/0/-/160, s. 1, 25, 35, 61, 68, 129, 169, 238, 257, 457, 487; sygn. 29/121/0/-/167, s. 274, 292, 325.

${ }_{76}$ ANKr, 29/121/0: Variae civitates et villae, sygn. 29/121/0/-/160, s. 7.

77 F. Sikora: Górka [parafia Koniusza]. W: SHGKr, Cz. 2, s. 5.

${ }^{78}$ Być może tożsamy z kmieciem był Świętek, wójt sądowy w tej wsi, wzmiankowany w latach 1487-1490. Por. W. Bukowski: Łaganów. W: SHGKr, Cz. 3, s. 791-794.

79 A. Marzec, W. Bukowski: Makocice-Gniazdowice. W: SHGKr, Cz. 4, s. 40.

${ }^{80}$ W. Bukowski: Łaganów..., s. 789.

${ }^{81}$ Wpis przyjęcia Jakuba Marszałka w poczet obywateli Proszowic jest niedatowany. Por. K. Nabiałek: Registrum hominum..., nr 180.

${ }^{82}$ ANKr, 29/121/0: Variae civitates et villae, sygn. 29/121/0/-/167, s. 383, 389; sygn. 29/121/0/-/160, s. 557.

${ }^{83}$ ANKr, 29/121/0: Variae civitates et villae, sygn. 29/121/0/-/160, s. 557.

${ }^{84}$ ANKr, 29/121/0: Variae civitates et villae, sygn. 29/121/0/-/160, s. 549.

${ }^{85}$ ANKr, 29/121/0: Variae civitates et villae, sygn. 29/121/0/-/167, s. 383.

${ }^{86}$ ANKr, 29/121/0: Variae civitates et villae, sygn. 29/121/0/-/167, s. 274-275, 327, 362, 364; sygn. 29/121/0/-/160, s. 487. 
zidentyfikować, to należy przyjąć, że wszyscy oni pochodzili z pobliskich wsi, a dwaj ostatni z sąsiadujących z Proszowicami Makocic (Budek - Aneks 2, nr 77) i Gniazdowic (Rafał - Aneks 2, nr 78) ${ }^{87}$.

Jest wiele osób, których identyfikacja nie jest możliwa lub jest dość wątpliwa. Szilina, wymieniona jako trzecia na liście, była być może żoną krawca Święszka Żyły, występującego w księdze miejskiej w 1451 roku $^{88}$. Podobnie nie sposób dowieść, że Lorkowa (Aneks 2, nr 36) jest tożsama z mieszczką wzmiankowaną w 1482 roku $^{89}$, a tym bardziej nie ma możliwości stwierdzić, czy mogłaby to być Anna Lorkowa, wdowa po Mikołaju vel Mikoszu Lor$\mathrm{ku}$ - rajcy Proszowic, poświadczonym źródłowo prawdopodobnie do 1474 roku $^{90}$. Nie można również z pewnością stwierdzić, czy Capynosova (Aneks 2, nr 73) była żoną lub może matką Stanisława Kapinoska — ławnika w kadencji $1505-1506^{91}$.

Zarówno liczebność, jak i pochodzenie (zwłaszcza spoza miasta) wpisanych do bractwa przekonują o dużym znaczeniu i popularności tej korporacji. Ścisły związek bractwa krawców z cechem krawieckim nie ulega wątpliwości. Przekonuje o tym treść wpisów zamieszczonych w całej składce. Nie ma jednak dowodów, że w okresie, gdy sporządzano wykaz członków bractwa, cech krawiecki formalnie już istniał. Zdaje się, że w XV wieku w Proszowicach rzemiosło krawieckie było dość dobrze rozwinięte, o czym świadczą stosunkowo liczni wymienieni w źródłach przedstawiciele tego zawodu ${ }^{92}$. O sprzyjających warunkach do uprawiania tego rzemiosła przekonuje też dość duża grupa krawców przyjętych do prawa miejskiego Proszowic (7 osób w szczątkowo zachowanej rejestracji z lat 1420-1455, najliczniejsza grupa zawodowa wśród wszystkich rzemiosł wskazanych przy nowo przyjętych) ${ }^{93}$. O ich znaczeniu w społeczności miejskiej świadczy również piastowanie przez tych rzemieśl-

${ }^{87}$ Oprócz nich byli to jeszcze: Martinus tritulator (młockarz?), Sosna i Świątek (Swÿathek).

${ }_{88}$ Być może to jej nazwisko powtórzono po raz drugi w wykazie (zob. przyp. 71). Por. ANKr, 29/121/0: Variae civitates et villae, sygn. 29/121/0/-/166, s. 214.

${ }^{89}$ ANKr, 29/121/0: Variae civitates et villae, sygn. 29/121/0/-/167, s. 149.

90 Mikołaj Lorek był w 1441 r. wójtem sądowym, a w latach 1443-1445, 1447—1448, 1454 i 1474 - rajcą. Być może to on był w 1433 r. ławnikiem. W 1446 r. występuje wraz z żoną Anną. Por. ANKr, 29/121/0: Variae civitates et villae, sygn. 29/121/0/-/166, s. 93, 102, 113 - 160, 179, 187-193, 231-232; sygn. 29/121/0/-/160, s. 6.

${ }_{91}$ ANKr, 29/121/0: Variae civitates et villae, sygn. 29/121/0/-/167, s. 518, 549, 564; sygn. 29/121/0/-/160, s. 634, 636, 649; F. Leśniak: W okresie Polski szlacheckiej..., s. 128 (podana niewłaściwa data sprawowania urzędu ławnika i nazwisko Kapinos zamiast Kapinosek).

${ }_{92}$ W najstarszej księdze miejskiej w latach 1418-1454 F. Kiryk stwierdził występowanie 8 krawców, podobnie jak kowali, którzy w XV w. cech zdołali założyć. Por. Tenże: Dzieje Proszowic..., s. 35; Tenże: Miasto średniowieczne..., s. 53.

${ }_{93}$ K. Nabiałek: Registrum hominum..., s. 152, nr 16, 53, 80, 103, 135; Tenże: Edycja rozproszonych wpisów rejestrów przyjęć do prawa miejskiego na przykładzie Proszowic i Sieradza. W: Editiones sine fine. Red. K. Kopiński, J. Tandecki. Toruń 2021, nr 47a, 47b. 
ników urzędów. Jan sertor był ławnikiem w 1426 roku, a przed 1433 rokiem rajcą $^{94}$. Michał sartor był w 1433 roku ławnikiem; ten sam Michał, albo inny rzemieślnik o tym imieniu, był rajcą w latach $1445-1448^{95}$. Ławnikiem był też w 1447 roku Marcin, krawiec ${ }^{96}$. Dodajmy, że w 2. poł. XV wieku cechy odgrywały istotną rolę w ustroju miejskim ${ }^{97}$. Dlatego jest dość prawdopodobne, że cech krawiecki powstał w XV wieku, zachowany zaś fragment księgi stanowi dokumentację tak cechu, jak i bractwa cechowego.

Dotychczas przyjmowano, że cech krawiecki powstał w 1547 roku $^{98}$. Zachowana składka akt pozwala przesunąć początki tego zrzeszenia wstecz co najmniej do 1535 roku. Warte podkreślenia jest, że F. Leśniak w części monografii Proszowic poświęconej dziejom nowożytnym wskazywał na brak ksiąg cechowych tego miasta. Historykowi temu nie były znane akta cechu krawców ${ }^{99}$. Z wizytacji diecezji krakowskiej z 1595 roku dowiadujemy się, że w XVI wieku i później współistniały ze sobą cech i bractwo cechowe krawców. Do obowiązków członków tej korporacji należała opieka nad ołtarzem św. Krzyża. Bractwo to (fraternitas sartorum) miało zostać zatwierdzone przez jednego z biskupów krakowskich o imieniu Jan ${ }^{100}$. W 2. poł. $\mathrm{XV}$ wieku i w 1. poł. stulecia następnego takie imię nosiło kilku biskupów: Jan Gruszczyński (pontyfikat: 1463-1464), Jan Lutek z Brzezia (1464-1471), Jan Rzeszowski (1471-1488), Jan Konarski (1503 - 1525), Jan Latalski (15361537), Jan Chojeński (1537-1538) ${ }^{101}$. Ponieważ w źródle tym niestety nie podano daty, więc nie wiadomo, kiedy doszło do zatwierdzenia korporacji i kto tego dokonat.

${ }^{94}$ ANKr, 29/121/0: Variae civitates et villae, sygn. 29/121/0/-/166, s. 5, 31, 58.

95 Tamże, s. 56, 163, 166, 168, 171, 173, 174, 191, 199.

96 Tamże, s. 192.

${ }^{97} \mathrm{~W}$ księgach miejskich cechy wymieniane są obok innych instytucji występujących w sprawach ogólnomiejskich — np. w 1488 r. przy zawarciu ugody między rajcami starymi a rajcami urzędującymi i pospólstwem wymieniono również przedstawicielstwo cechowe: „inter Clementem Slonko, Gregorium Koczyela, Albertum Masgaÿ, Mathiam Sbischek antiquos conules ex una et inter Johannem funificem, Johannem Janusz, Stanislaum Panek, Mathiam Sbischek etc. consules protunc sedentes una cum iuratos necnon cechi pariter cum tota comunitate civitatis partibus ex altera" - ANKr, 29/121/0: Variae civitates et villae, sygn. 29/121/0//167, s. 207-208.

98 F. Leśniak: W okresie Polski szlacheckiej..., s. 177. Podstawą do takiego wniosku była wzmianka o statucie cechowym z tego roku w lustracji z 1660 r. (Lustracja województwa krakowskiego 1659-1664. Cz. 2. Wyd. A. Falniowska-Gradowska, F. Leśniak. Warszawa 2005, s. 377).

99 F. Leśniak: W okresie Polski szlacheckiej..., s. 186.

100 AMetrKra, AVCap. 65, k. 250v.

101 B. Kumor: Dzieje diecezji krakowskiej do roku 1795. T. 1. Kraków 1998, s. 509—513. 


\section{Wnioski}

W przedstawionym studium omówione zostały dwa średniowieczne rękopisy, które stanowią dokumentację działalności dwóch organizacji rzemieślniczych z Proszowic. Oba zostały założone w XV wieku. W wypadku kowali można mówić o całej księdze. Dla krawców najpewniej zachowała się część akt, gdyż dysponujemy tylko jedną składką. Ze względu na użycie do sporządzenia obu ksiąg identycznego papieru można przyjąć, że założono je w latach 80. lub na przełomie lat 80. i 90. XV wieku. Być może również obie korporacje rzemieślnicze powstały w zbliżonym czasie. Sprawą otwartą pozostaje pytanie: jaki był charakter tych zrzeszeń? W obu księgach określano je terminem fraternitas, który, w zależności od kontekstu, może oznaczać zarówno cech, jak i bractwo religijne. Możliwe, że początkowo były to bractwa religijne, które z czasem przekształciły się w cechy. Równie prawdopodobne jednak jest to, że w chwili założenia ksiąg zrzeszenia te miały już charakter zarówno cechu, jak i bractwa. Taki wniosek jest uprawniony w odniesieniu do księgi kowali, jeśli weźmie się pod uwagę treść wpisów. W wypadku krawców nie jest to już pewne. Wpisy z XV wieku w zachowanej składce dotyczą bractwa rzemieślniczego. Nie można wykluczyć, że w tym czasie powstał również cech krawiecki, ale nie ma takiej pewności.

Zawartość składek powstałych w cechu kowali z początkowego okresu, a więc z XV wieku, nie wskazuje na istnienie potrzeby prowadzenia bieżącej dokumentacji. Rękopis miał najpewniej służyć celom prestiżowym. Być może miał to być rodzaj kroniki cechowej. Nie wydaje się, aby księga ta miała przełożenie na codzienne funkcjonowanie cechu. Wpisy najstarsze — statutów oraz członków bractwa — nie zostały dokończone; kolejne, które się pojawiły, pochodziły dopiero z 2. poł. XVI wieku.

W wypadku zachowanej składki księgi krawców widać zamiar zarejestrowania prawdopodobnie pełnego składu członków bractwa cechowego, ale wpisy odnoszące się do praktyki cechowej pochodzą dopiero z trzeciego dziesięciolecia XVI wieku.

Istotna jest jednak sama potrzeba założenia przez te korporacje księgi wpisów. Świadczy to o upowszechnieniu się kultury pisma wśród mieszczan. Można zaryzykować też hipotezę, że decyzja o założeniu rękopisu podjęta została pod wpływem innego ośrodka. Kilka lat wcześniej księgę dla bractwa kowali założono w Bochni, mieście oddalonym od Proszowic o $30 \mathrm{~km}$. Ta zbieżność czasowa i zawodowa twórców księgi może być nieprzypadkowa. Proszowickim kowalom mogło jednak później zabraknąć determinacji do prowadzenia systematycznej dokumentacji. Dopiero pod koniec następnego stulecia zaczęto w praktyczny sposób wykorzystywać rękopis i wprowadzać do 
niego już liczne wpisy. To może być jeden z argumentów przemawiających za naśladownictwem.

Można spróbować sformułować pewne wnioski na temat kancelarii obu zrzeszeń. Księgi kowali i krawców zostały spisane różnymi rękami. Jednocześnie w zachowanych $\mathrm{z}$ tego samego okresu, a więc z ostatniej ćwierci XV wieku, księgach ławniczych Proszowic nie udało się odnaleźć żadnej z tych rąk. Porównanie pisma z fragmentów ksiąg radzieckich i ksiąg ławniczych Proszowic z tego samego okresu (1449-1452, 1454 oraz 1670-1671) pozwala przyjąć, że miasto utrzymywało jednego pisarza, który redagował wszystkie akta $^{102}$. W kancelariach cechowych utrzymywano zatem osobnych pisarzy albo - co bardziej prawdopodobne - jeden z członków zrzeszenia prowadził dokumentację ${ }^{103}$. Funkcję pisarza mógł także pełnić duchowny związany z bractwem cechowym ${ }^{104}$. Być może dalsze kwerendy źródłowe pozwolą lepiej poznać dokumentację własną średniowiecznych korporacji rzemieślniczych w Proszowicach.

\section{Aneks 1}

Wykaz członków bractwa kowali Proszowicz z 1483 roku.

Oryginat: Biblioteka Jagiellońska w Krakowie, rkps 1111, s. 21.

||Fratres unacum sororibus inditi fraternitati fabrili in Proschowicze 1483\|.

In civitate habitantes:

1. Martinus Rudnyk

2. Clemens Slunko

3. Sowka

4. Paulus braxator cervisie

5. Nicolaus Cchlebiczka [?]

6. Cula braxator cervisie

7. Leonardus serifaber mortuus

8. Paulus faber mortuus

${ }^{102}$ K. Nabiałek: Księgi miejskie Proszowic..., s. 317-318.

${ }_{103}$ Praktykę prowadzenia ksiąg przez jednego z członków zaobserwował w uboższych i mniej licznych cechach Torunia J. Tandecki: Kancelarie toruńskich korporacji rzemieślniczych..., s. 51.

${ }^{104}$ Pełnienie funkcji altarysty, a zarazem pisarza brackiego, stwierdził F. Kiryk w księdze bractwa kowali w Bochni. Por. Tenże: Bractwo religijne kowali..., s. 116. 
9. Johannes faber mortuus

10. Nicolaus braxator cervisie

11. Anthonius sutor

12. Johannes Pranchnicz presbiter fraternitatis.

Aneks 2

Wykaz członków bractwa krawców Proszowic, wpisy prawdopodobnie z ostatniej ćwierci XV i poczatku XVI wieku.

Oryginat: Archiwum Diecezjalne w Kielcach, Akta parafialne II, sygn. II PP-XVI/1, k. 20-21v.

[k. 20]

1. ${ }^{a-D e x i a n k o w a ~}$

2. |-Liszka anticus-|

3. Szilina

4. Szunkowa

5. |-Cz-| Coczelya

6. |-Szolnyerz-|

7. Szupka Johannes

8. Oszowsky

9. $\mid-\left[\mathrm{S}^{b}\right]$ zawfranczowa-|

10. Dunaÿ

11. Mirzwa

12. Rabadek [?]

13. Cobyelina

14. Szwinka

15. Miczkouicz ${ }^{c}$

16. Byaly

17. Biska

18. Martinus Mloczek

19. Jach

20. Rasnÿ Jacobus

21. Blasius pistor

22. Nosczina

${ }^{b}$ w miejscu litery wycięta dziura na sznurek taczacy poszyt - widoczny tylko górny tuk, prawdopodobnie majuskułowej litery S; na taka rekonstrukcję wskazuje też ortografia stosowana przez pisarza w innych nazwiskach,

${ }^{c}$ w górnej części pierwszej litery wyrazu wycięta dziura na sznurek taczący poszyt, 
[k. 20v]

23. Sbythny

24. Nobilis Stanislaus Maslowsky

25. Thomas pistor

26. Swyatek de Laganow

27. Szosnka

28. Jacobus de Gnyasdouicze

29. Nobilis Laganowsky Johannes

30. Hedwys Rzimska

31. Wawrzinczowa

32. Masur

33. Gutowicz

34. Nyedzwyedz

35. Marszalek

36. |-Lorkowa-|

37. Nicolaus Pach

38. Rrzaycza [?] in maccelis [s]

39. Paszek malÿ

40. Szadÿ

41. Grabolusk

42. |-Spitarsky-|

43. |-Krepla-|

44. Haladasz ${ }^{-d}$

[k. 21]

45. ${ }^{e-S r o t h k a ~ S t a n i s l a u s ~ s u s c e p i t ~ f r a t e r n i t a t e m ~ s a r t o r u m ~ e t ~ n i c h i l ~ f e c i t ~ a d ~ f r a t e r n i t a t e m ~}$ ni[ chi $\left.^{f}\right] 1$ persolvit.

46. Spyk Stanislaus ni[chif $] 1$ fecit ad fraternitatem.

47. Vrban

48. Zylyna

49. Rosna

50. Szubka

51. Jacobus de Makoczÿcze

52. Piscorek

53. Voythowna

54. Kosczyen

55. Gawlova

56. Cosnowna ${ }^{g}$

57. Woythas

a-d tekst sporządzony ręka $n r$,

${ }^{f}$ jest zapis: nil ze znakiem ściagnięcia; przyjęto ortografię wedtug petnego zapisu wyrazu w tym samym fragmencie,

g lewej części pierwszej litery wyrazu wycięta wtórnie dziura na sznurek taczacy poszyt, 
58. Glowka

59. |-Sbigneus-|

60. |-Thomas pistor-|

61. Borek

62. Szymkova

63. Boczyønek

64. Myrzwa

65. Stayennÿ

66. Poczyelyøczyv wlasl

67. |-Thalaphus-|

68. Adam

69. Lysczyna

70. Cropak

71. Thvmÿstoÿ

[k. 21v]

72. Thyrka

73. Capynosova

Item villani:

74. Martinus tritulator

75. Sosna

76. Swÿathek

77. Budek de Makoczÿcze

78. Raphal de Gnyasdovycze ${ }^{-h}$

79. ${ }^{i-S o b o c z s z k y ̈ ~ C l i m e k ~ k r a m a r z ~ s u s c e p i t ~ f r a t e r n i t a t e m ~ c u m ~ s a r t o r i b u s ~}{ }^{-j}$.

80. ${ }^{k}$ Kvrpÿel suscepit fraternitatem suscepit [s] et 2 g[rossos] dedit tamen ${ }^{l}$ [?] et nihil aliud fecit ${ }^{-m}$.

81. ${ }^{n-}$ Gladiator suscepit fraternitatem cum sartoribus ${ }^{-o}$.

\footnotetext{
${ }^{e-h}$ tekst od $n r 45$ do $n r 78$ pisany ręka $n r 2$,

i-j wpis sporządzony ręka $n r 3$,

l odczyt niepewny - jest: tm ze znakiem skrócenia,

$k-m$ wpis sporzadzony ręka $n r 4$,

n-o wpis sporządzony ręka $n r 5$, prawdopodobnie z początku XVI w.
} 


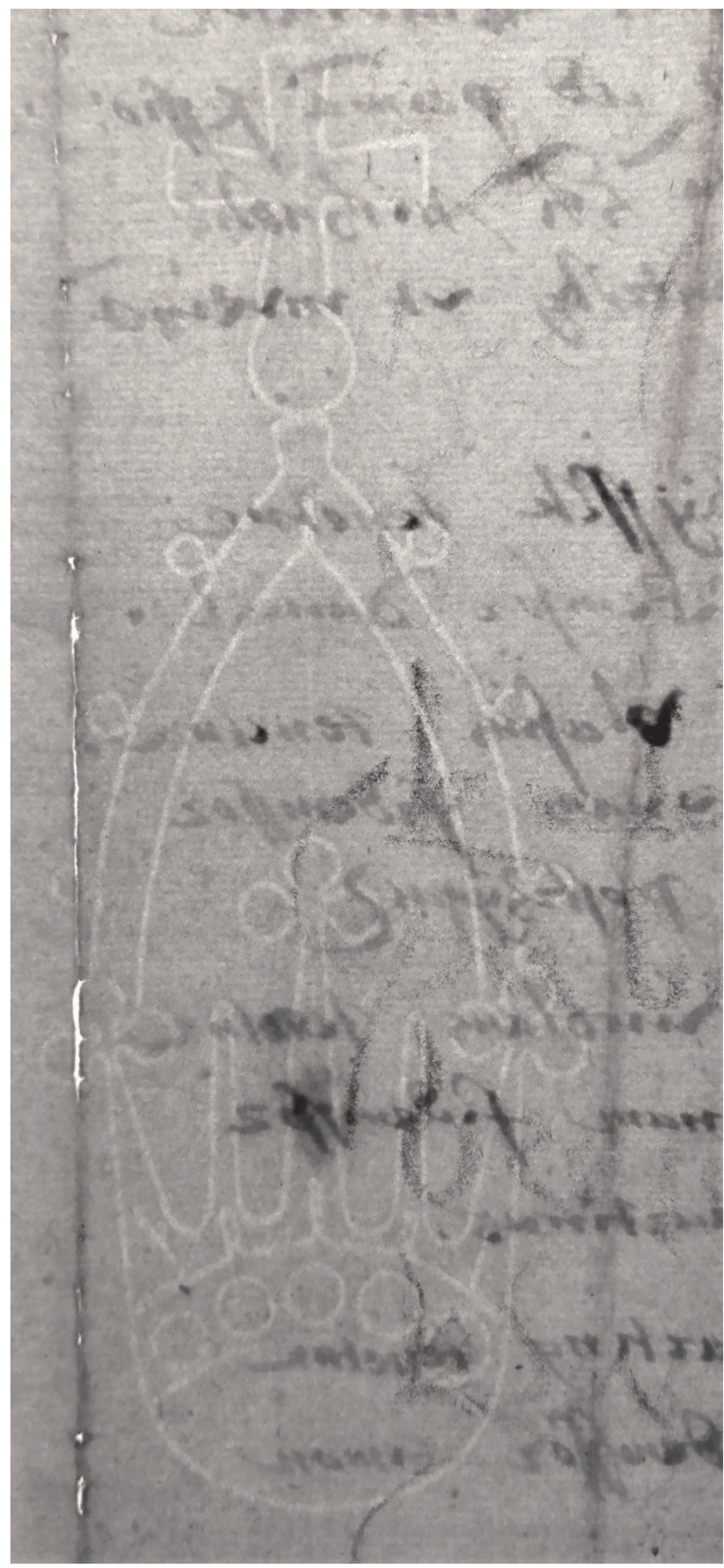

Fot. 1. Znak wodny z papieru księgi kowali Proszowic.

BJ, rkps 1111, s. $31-32$ i $37-38$ 


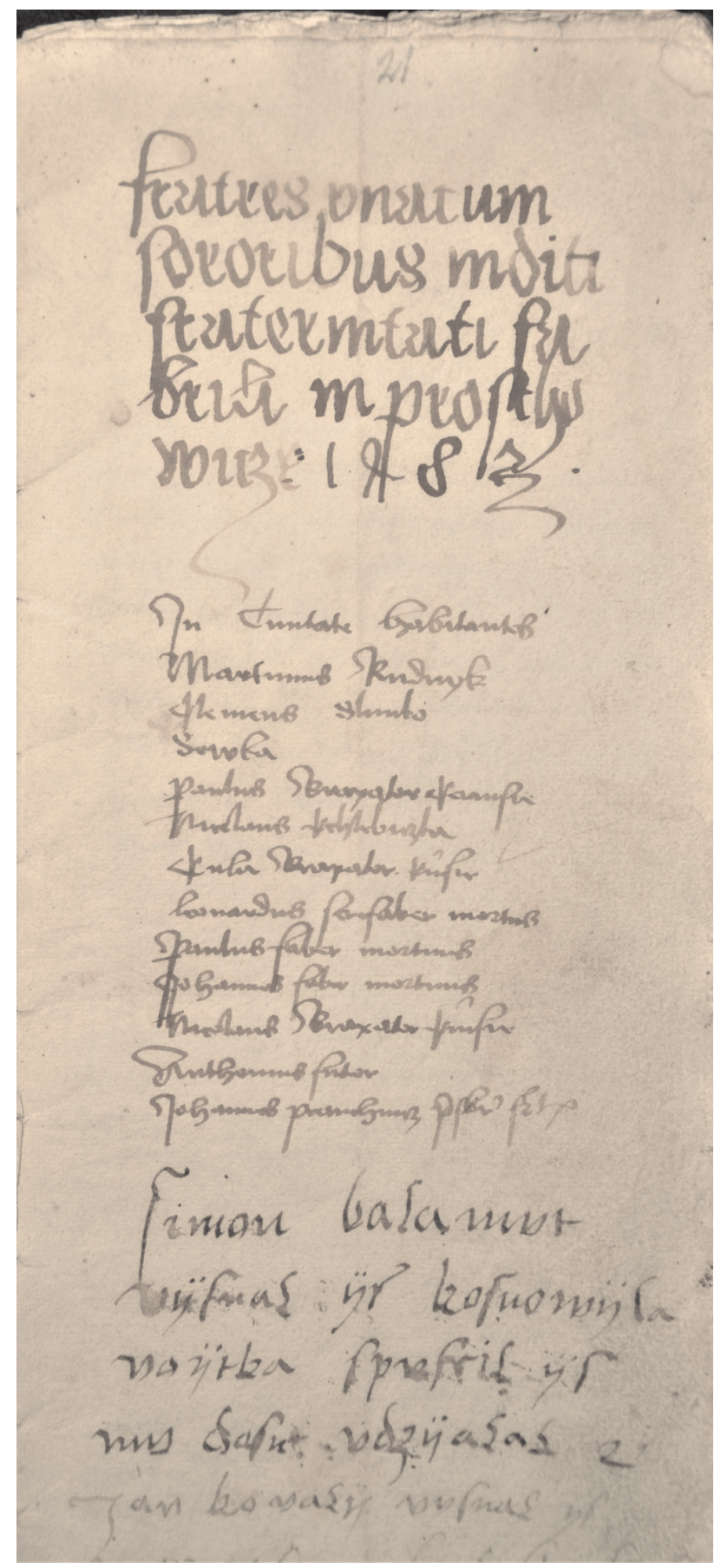

Fot. 2. Fragment księgi kowali Proszowic z wykazem członków bractwa z 1483 roku. BJ, rkps 1111, s. 21 


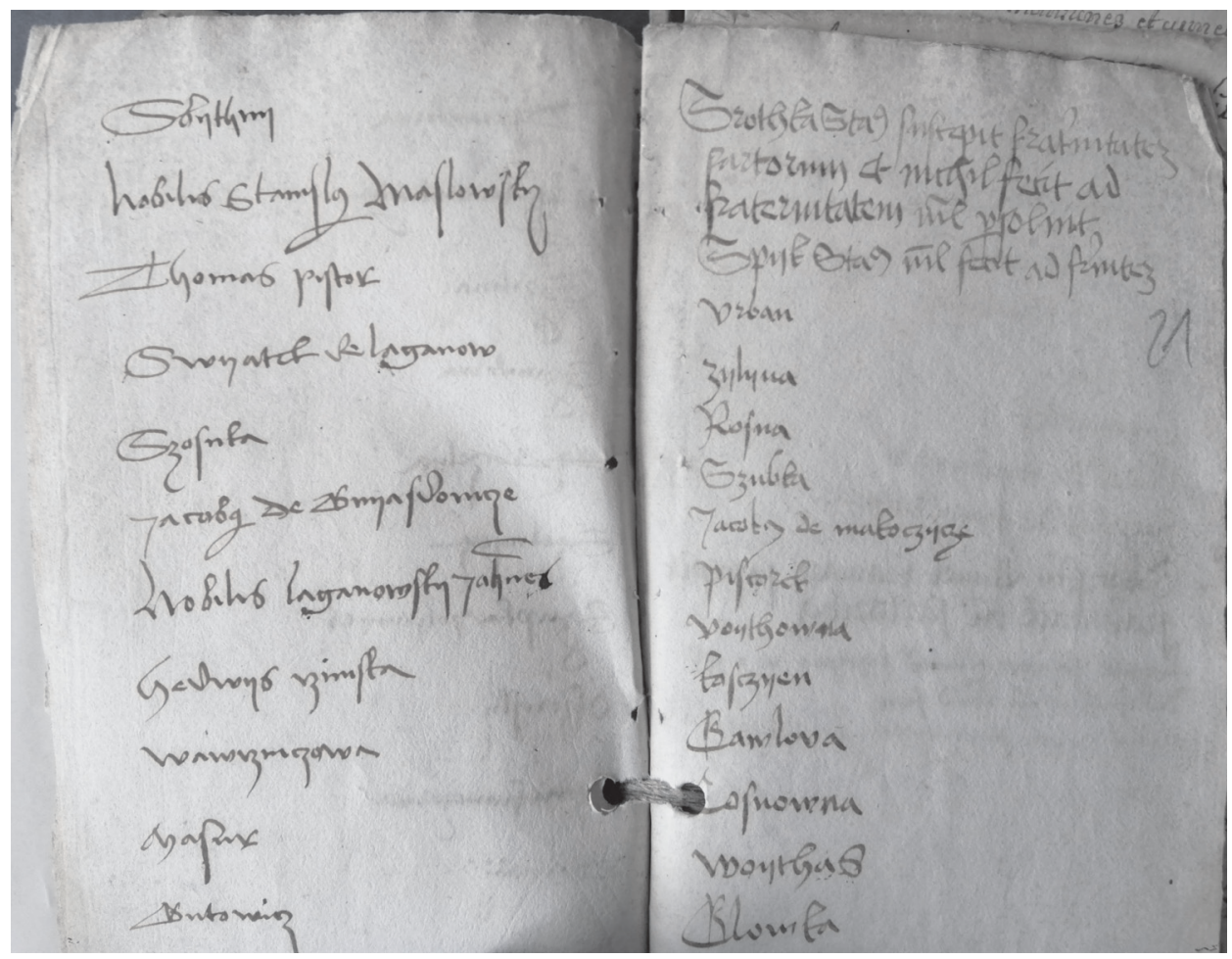

Fot. 3. Fragment księgi krawców Proszowic z wykazem członków bractwa. Archiwum Diecezjalne w Kielcach, Akta parafialne II, sygn. IIPP-XVI/1, k. 20v-21

\section{Bibliografia}

\section{Źródla rękopiśmienne}

Archiwum Diecezjalne w Kielcach: Akta parafialne II, sygn. IIPP-XVI/1.

Archiwum Główne Akt Dawnych w Warszawie: Księgi Wpisów Metryki Koronnej, 17.

Archiwum Kurii Metropolitalnej w Krakowie: Acta episcopalia Cracoviensia, sygn. 1, 29; Acta

Visitaciones capituli, sygn. AVCap. 65.

Archiwum Narodowe w Krakowie: zespół nr 29/121/0: Variae civitates et villae, sygn. 29/121/ 0/-/160, 29/121/0/-/161, 29/121/0/-/166, 29/121/0/-/167, 29/121/0/-/281.

Biblioteka Jagiellońska w Krakowie: rkps 1111.

Muzeum Ziemi Miechowskiej: dokument o sygn. MZM/P/3. 


\section{Źródla drukowane}

Księga cechowa złotników krakowskich 1462-1566. Tekst oprac. B. Dybaś, J. Tandecki. Warszawa 2000 (Złotnicy krakowscy XIV-XVI wieku i ich księga cechowa, T. 2).

Lustracja województwa krakowskiego 1659-1664. Cz. 1-3. Wyd. A. Falniowska-Gradowska, F. Leśniak. Warszawa 2005.

Materiaty do Kodeksu dyplomatycznego Małopolski. T. 5: 1451-1506. Oprac. W. Bukowski, F. Sikora, J. Wroniszewski. Red. W. Bukowski, przy współpr. J. Szyszki. Kraków 2014. Dostępne w Internecie: http://www.kodeks.pau.krakow.pl/dokumenty.html [data dostępu: 20.12.2020].

Metryka Uniwersytetu Krakowskiego z lat 1400-1508. Wyd. A. Gąsiorowski, T. Jurek, I. Skierska, przy współpr. R. Grzesika. Kraków 2004.

Najstarsza księga promocji Wydziatu Sztuk Uniwersytetu Krakowskiego z lat 1402-1541. Wyd. A. Gąsiorowski, T. Jurek, I. Skierska. Warszawa 2011.

Wojnickie księgi cechowe. T. 1: Księgi wpisów cechu wielkiego. Wyd. J. Chumiński, J. Szymański. Wojnicz 1998.

\section{Opracowania}

Bartoszewicz A.: Piśmienność mieszczańska w średniowiecznej Polsce. Warszawa 2012.

Baza filigranów Hauptstaatsarchiv Stuttgart, opracowana na podstawie wydawnictwa Piccarda — www.piccard-online.de [data dostępu: 22.01.2021].

Bukowski W.: Laganów. W: Słownik historyczno-geograficzny województwa krakowskiego w średniowieczu. Cz. 3. Oprac. W. Bukowski, J. Kurtyka, J. Laberschek, Z. Leszczyńska-Skrętowa, A. Marzec, F. Sikora, M. Wilamowski, M. Wolski. Kraków 1994-2003.

Catalogus codicum manuscriptorum medii aevi Latinorum qui in Bibliotheca Jagiellonica Cracoviae asservantur. Vol. 6. Composuerunt M. Kowalczyk, A. Kozłowska, M. Markowski, L. Nowak, A. Sobańska, R. Tatarzyński, S. Włodek, M. Zwiercan. Cracoviae 1996.

Czarciński I.: Bractwa $w$ wielkich miastach państwa krzyżackiego $w$ średniowieczu. Toruń 1993.

Jagiellońska Biblioteka Cyfrowa: https://www.jbc.bj.uj.edu.pl/dlibra [data dostępu: 25.09.2020]. Kiryk F.: Bractwo religijne kowali w Bochni w latach 1462-1559. W: „Zeszyty Naukowe Uniwersytetu Jagiellońskiego". Prace historyczne, z. 56. Kraków 1977.

Kiryk F.: Dzieje Proszowic w epoce piastowskiej i jagiellońskiej. „Rocznik Naukowo-Dydaktyczny Wyższej Szkoły Pedagogicznej w Krakowie” 1967, z. 26 (Prace Historyczne, z. 3).

Kiryk F.: Miasto średniowieczne. W: Proszowice. Zarys dziejów do 1939 roku. Red. F. Kiryk. Kraków 2000.

Kiryk F.: Rzemiosła i organizacje rękodzielnicze w małopolskich miastach górniczych. „Teki Krakowskie" 1997, [T.] 5.

Kropidłowski Z.: Samopomoc w korporacjach rzemieślniczych Gdańska, Torunia i Elblaga (XIV-XVIII w.). Gdańsk 1997.

Kumor B.: Dzieje diecezji krakowskiej do roku 1795. T. 1. Kraków 1998; T. 4. Kraków 2002. 
Leśniak F.: W okresie Polski szlacheckiej. W: Proszowice. Zarys dziejów do 1939 roku. Red. F. Kiryk. Kraków 2000.

Litak S.: Bractwa religijne w Polsce przedrozbiorowej XIII-XVIII wiek. Rozwój i problematyka. „Przegląd Historyczny” 1997, T. 88, z. 3/4.

Marzec A., Bukowski W.: Makocice-Gniazdowice. W: Stownik historyczno-geograficzny województwa krakowskiego w średniowieczu. Cz. 4. Oprac. W. Bukowski, J. Laberschek, Z. Leszczyńska-Skrętowa, A. Marzec, M. Mikuła, K. Nabiałek, F. Sikora, J. Szyszka, M. Wilamowski, M. Wolski, M. Zdanek. Kraków 2006-2014.

Nabiałek K.: Bractwo klasztoru św. Katarzyny z Góry Synaj w miastach polskich (Żarnowiec, Sienno, Wieluń). W: Felix indiget amicis. Studia z dziejów kultury duchowej i intelektualnej średniowiecza ofiarowane Profesorowi Krzysztofowi Ożogowi. Red. W. Świeboda, M. Zdanek. Kraków 2016.

Nabiałek K.: Edycja rozproszonych wpisów rejestrów przyjęć do prawa miejskiego na przykładzie Proszowic i Sieradza. W: Editiones sine fine. Red. K. Kopiński, J. Tandecki. Toruń 2021.

Nabiałek K.: Księgi miejskie Proszowic z XV-XVIII wieku. Studium kodykologiczne. „Archeion" 2019, T. 120.

Nabiałek K.: Registrum hominum ius civile susceptorum. Rejestr przyjęć do prawa miejskiego Proszowic z XV wieku. „Średniowiecze Polskie i Powszechne” 2018, T. 10 (14).

Pietrusiński J.: Złotnicy krakowscy XIV—XVI wieku i ich cech. Warszawa 2000 (Złotnicy krakowscy XIV-XVI wieku i ich księga cechowa, T. 1).

Ptaśnik J.: Miasta i mieszczaństwo w dawnej Polsce. Wyd. 2. Warszawa 1949.

Rajman J.: Rajcy krakowscy i członkowie ich rodzin w księdze zmartych bractwa Najświętszej Marii Panny w Krakowie (połowa XIV—koniec XVI wieku). „Średniowiecze Polskie i Powszechne" 2015, T. 7 (11).

Schmidt M.: Sądownictwo cechów krakowskich w średniowieczu w świetle ksiąg cechowych. W: „Zeszyty Naukowe Uniwersytetu Jagiellońskiego”. Prace historyczne, nr 142, z. 1. Kraków 2015.

Sikora F.: Górka [parafia Koniusza]. W: Stownik historyczno-geograficzny województwa krakowskiego w średniowieczu. Cz. 2. Oprac. J. Kurtyka, J. Laberschek, Z. Leszczyńska-Skrętowa, F. Sikora. Red. F. Sikora. Wrocław-Kraków 1989-1993.

Stownik łaciny średniowiecznej w Polsce. T. 4: F-H. Red. M. Plezia. Wrocław-WarszawaKraków-Gdańsk 1975-1977.

Słownik polszczyzny XVI wieku. T. 3: By-Cyzyjojanus. Wrocław-Warszawa-Kraków 1968.

Stownik staropolski. T. 1: A-Ć. Warszawa 1953-1955.

Starzyński M., rec.: A. Bartoszewicz: Piśmienność mieszczańska w średniowiecznej Polsce. Warszawa 2012. „Roczniki Historyczne” 2012, T. 88.

Tandecki J.: Dokumenty i kancelarie miejskie. W: Dyplomatyka staropolska. Red. T. Jurek. Warszawa 2015.

Tandecki J.: Kancelarie toruńskich korporacji rzemieślniczych $w$ okresie staropolskim. Warszawa-Poznań-Toruń 1987 (Roczniki Towarzystwa Naukowego w Toruniu, 82, z. 3).

Tandecki J.: Struktury administracyjne i spoleczne oraz formy życia $w$ wielkich miastach Prus Krzyżackich i Królewskich w średniowieczu i na progu czasów nowożytnych. Toruń 2001.

Tandecki J.: Średniowieczne i nowożytne źródła do dziejów rzemiost skórniczych. W: J. Tandecki: Szkice z dziejów Torunia i Prus w średniowieczu i na progu czasów nowożytnych. Toruń 2008.

Testamenty z ksiag sadowych matych miast polskich do 1525 roku. Oprac. A. Bartoszewicz, K. Mrozowski, M. Radomski, K. Warda. Red. A. Bartoszewicz. Warszawa 2017. 
Wisłocki W.: Katalog rękopisów Biblioteki Uniwersytetu Jagiellońskiego. Cz. 1—2. Kraków 1877-1881.

Wiśniewski J.: Dekanat miechowski. Radom 1917.

Wiśniowski E.: Bractwa religijne na ziemiach polskich w średniowieczu. „Roczniki Humanistyczne" 1969, T. 17, z. 2.

Wiśniowski E.: Parafie $w$ średniowiecznej Polsce. Struktura i funkcje społeczne. Lublin 2004.

Wolff A.: Projekt instrukcji wydawniczej dla pisanych źródeł historycznych do połowy XVI wieku. „Studia Źródłoznawcze” 1957, T. 1.

Wółkiewicz E.: Kościót i jego wierni. Struktury kościelne i formy pobożności w średniowiecznej Nysie. Kraków 2014.

Wyrozumski J.: Tkactwo małopolskie w późnym średniowieczu. Warszawa-Kraków 1972.

Wyrozumski J.: Związki czeladnicze w Polsce średniowiecznej. „Przegląd Historyczny” 1977, T. 68

Zaremska H.: Bractwa w średniowiecznym Krakowie. Studium form społecznego życia religijnego. Wrocław-Warszawa-Kraków-Gdańsk 1977.

Żurek D.: Przestrzeń i spoleczeństwo Chrzanowa średniowiecznego i nowożytnego. Kraków 2015.

\section{Karol Nabiatek}

Books of the Craft Corporations of Proszowice from the 15th Century A Contribution to the Study of Urban Literacy in the Middle Ages

Summary

In his article, Karol Nabiałek is concerned with the documentation of craft guilds from the city of Proszowice in the Kraków area (Małopolska or Lesser Poland). He examines two manuscripts - the blacksmiths' and the tailors'. Both books were probably started in the 1480s and were kept through the sixteenth and eighteenth centuries. The appropriate method of dating of such books must be based identifying the paper on which they are written. Nabiałek has prepared codicological descriptions and carried out an overview of the contents of both manuscripts. He has made an attempt to determine the status of these corporations. The blacksmiths' manuscript was probably both a guild and a confraternity book. The tailors' files initially contained a list of members of the religious confraternity, and, from the sixteenth century on, matters of the guild were entered in them. These manuscripts are rare examples of extant landmark works of medieval writing of professional craft corporations preserved in Poland.

Keywords: corporate books, guilds, fraternity, urban literacy, codicology 


\section{Karol Nabiatek}

Die Bücher von Handwerkskorporationen der Stadt Proszowice aus dem 15. Jahrhundert

Ein Beitrag zur Forschung über die mittelalterlichen Schriftlichkeit

Zusammenfassung

Der Artikel beschäftigt sich mit der Selbstdokumentation von Handwerkerzünften aus der Stadt Proszowice im Krakauer Land (Kleinpolen). Es werden zwei Manuskripte behandelt, und zwar die Handschriften von Schmieden und Schneidern. Beide Bücher entstanden wahrscheinlich in den 1480er Jahren und wurden vom 16. bis zum 18. Jahrhundert weitergeführt. Für die Datierung der Bücher ist die Identifizierung des Papiers, auf dem sie verfasst wurden, entscheidend. Es wurden kodikologische Beschreibungen erstellt und der Inhalt der beiden Handschriften charakterisiert. Des Weiteren wurde ein Versuch unternommen, den Status der Korporationen zu ermitteln. Im Falle der Handschrift von Schmieden handelte es sich wahrscheinlich sowohl um das Zunft- als auch um das Bruderschaftsbuch. Die Akten von Schneidern enthielten zunächst ein Verzeichnis der Bruderschaftsmitglieder und ab dem 16. Jahrhundert wurden darin auch die Angelegenheiten der Zunft eingetragen. Die erhaltenen Manuskripte bilden seltene Beispiele für mittelalterliche Handschriften der Berufskorporationen aus dem Gebiet Polens.

Schlüsselwörter: Bücher der Handwerkskorporationen, Zunft, Bruderschaft, Schriftlichkeit, Kodikologie 